\title{
Kelamcıların Bilgi Tanımları Üzerine Bir Tahlil Denemesi
}

\author{
Muhit MERT \\ Doç. Dr., Gazi Üniversitesi Çorum İlâhiyat Fakültesi \\ e-mail: muhitmert@hotmail.com
}

Abstract: An Essay of Analysis on the Definition of Knowledge of Kalam Scholars. This article examines the nature of knowledge and its characteristics according to Kalam Scholars. First of all, I discuss whether knowledge can be definable or not, then deal with the definitions of knowledge according td Theologians of Mutezilete and ahl al-Sunna and evaluate these definitions according to technical norms of definition. In this context, I show the meanings and denotations of the terms that are used in their definitions and point out the philosophical bases of them.

Key Words: 1. Definition, Knowledge, Belief, Truth, Certainty, Trust, Kalam

\section{Giriş}

Bilgi ve bilmek kelimeleri belki de hayatta en çok kullandığımız kavramlardandır. Bunun nedeni, varlıkla ilişkimizin zihinsel bir boyutu olan bilme eyleminin pek çok vasıtaya dayalı olarak hayatın büyük bir bölümüne yayılması olsa gerek. Kimi zaman bir duyumsamayla, kimi zaman da aldığımız bir haberle ilişkili olarak bir şeyi bildiğimizi söyleriz. Bazen bir takım delillerden, karinelerden hareket ederek bir şeyi bildiğimize hükmeder, bazen de bir şeyi tecrübe ederek ve bu tecrübeyi defalarca tekrar- 
layarak o şeyin bilgisine ulaştığımıza inanırız. Kimi zaman bir şeyin bilgisinin zorunlu olarak zihnimizde var olcuğunu söyler, kimi zaman da bir şeyi sezinleyerek, o şeyin içimize doğduğunu söyleyerek bildiğimizi zannederiz. Ama bildiğimizi söylediğimiz o şeylerin bir hakikatle uyum içinde olup olmadığını, bir gerçekliğ̣i yansıtıp yansıtmadığını çoğu zaman bilmeyiz. Bir de zihinsel bir süreci if ade eden bilginin veya bilmenin ne olduğunu, nasıl ve hangi kaynaklar vasıtasıyla oluştuğunu, hangi evreleri geçirdiğini pek göz önünde bulundurmayız.

Bilginin ne olduğunu bilmek de aslında bilgi ile ilgili bir sorundur. "Bilgi nedir?" sorusuna verilecek cevap onun ne olduğunu ortaya koyacaktır. Bir şey hakkında, nedir? diye sormak, onun hakikatini bilmeye yönelmektir. $\mathrm{Bu}$ da felsefenin önemli bir problemidir. Bir şeyin hakikatini bilmek ise, onu tanımlamakla mümkün olur. Tanım ise mantığın bir problemidir. Bilginin tanımlanmasında da mantı乡̆, in tanım teorisinden yararlanılır. Kelam ilmi, temelde felsefenin sorularıyla ilgilenir ve mantığın metotlarından yararlanır. Bu nedenle kelamcılar da bilginin neliğini konu edinir ve onu tanımlamaya çalışırlar.

Kelam ilminin kapsamına giren konular üzerine konuşmak, ancak onun epistemoloji ve ontoloji ile ilgili olarak ortaya koyduklarını bilmekle mümkündür. Aksi takdirde bu alanla ilgili konularda konuşmak imkânsızlaşır. Hicrî III. Asrın sonlarındın itibaren kelam kitaplarına yüzeysel olarak bakıldığında bile hemen görüleceği üzere ilk konular, bilgi teorisiyle ilgilidir. Peşinden de ontolojiyle ilgili hususlar gelir. Bunun nedeni; bilgi konusunda söyleneceklerin, daha sonra gelen ontoloji ve teolojiyle ilgili konular için bir temel, bir hazırlık safhası oluşturmasıdır. Kelamın bilgi teorisi; bilginin tanımıyla başlayıp, imkânı ve kaynakları üzerine yapılan tartışmalarla devam etmelitedir. Bu noktada bilgi üzerine konuşmanın aslında ortaya konulacak olan dünya görüşünü temellendirmek anlamına geldiğini söyleyebiliriz. Bu konuda takınılacak idealist, rasyonalist, septik vb. tavırlar; varlık, ahlâk, estetik anlayışlaııı da belirleyecektir. Kısaca, ontoloji, teoloji, etik ve estetikle ilgili söylemlerin bilgi teorisi üzerine oturduğunu söyleyebiliriz. Örneğin varlığın bilinebileceğini söylemek, onun var olduğunu söylemekle; var olduğunu söylemek, var edenin varlığıyla ilişki kurmakla; varlıktan ve var edenden bahsedebilmek de onları bilmekle mümkün olur. Bu derece öremli bir konunun girişi olarak düşünebileceğimiz bilginin tanımını tartışmak da şüphesiz ki, konusu, imkânı, kaynakları gibi hususlarla ilişkili olduğundan önem arzetmektedir.

Burada şunu hemen belirtelim ki kelamda bilginin ne olduğu konusunda ortaya konmuş tek bir tanırn yoktur. Bilgi kelamcılar tarafından farklı terimlerle ve farklı biçimlerde t:anımlanmıştır. Ancak yapılan tanımların bilginin gerçekliğini ifade edip etmedikleri de tartışma konusu olmuştur. Bu çalışmada biz, kelamcıların bilgi tanımları üzerinde duracağız. Bu tanımların; tanımın tekniği, kavramların kullanımı, bunların diğer kelamî problemlerle bağıntıları gibi yönlerden bir incelemesini yapacağız. 
Ancak bilgi tanımlarının tahliline geçmeden önce kelamcıların tanım teorisinden de bahsetmemiz gerekir, çünkü bu, yapılan tanımları değerlendirmek bakımından faydalı olacaktır. Fakat bunu yapmak ayrı bir çalışmayı gerektirecek kadar hacimli olacağından bu konuyu başka bir makaleye tehir ediyor ve burada sadece bilginin tanımlanıp tanımlanamayacağı konusuna yer veriyoruz. Bu bize kelamcıların tanımdan ne anladıklarına dair ipuçlarını da verecektir.

Teknik anlamda tanım yapmak aslında başlı başına bir zorluk içerir. Çünkü bir şeyi tanımlamak için, onun varlık kategorisinde bulunduğu yeri, cins ve fasla/ayrıma göre belirlemek gerekiyor. Bu yüzden üstün cinsler ve türü olmayan fertler ile duygular ve duyuların doğrudan tecrübeleri tanımlanamazlar kategorisinde değerlendirilirler.' Zira bunların ya özsel karakterleri tespit edilemez ya da bir cins içinde bulunmazlar. Bu açıdan bakıldığında zihin dışı varlığa delalet eden kavramlanı tanımlamak; duyumsanan şeylerle ilgili olduğundan, yalnızca zihinsel varlığı olan kavramların tanımlanmalarından daha kolay gözükmektedir. Ama zihin dışı varlığ da, türün ayırıcı vasfını tespit etmek oldukça zordur. Dikkat edilirse tanımlamalarda hep insan tanımı örnek olarak verilir ve ayırıcı özellik olarak da konuşma gösterilir. Bunu bir koyun, bir maymun ya da bir zebra üzerinde düşündüğümüzde zorluk daha iyi anlaşılacaktır. Bunları cins içindeki benzer-lerinden ayıran, onları koyun, maymun ve zebra yapan temel nitelikler nelerdir? İşte onları tanımlamak için bunu bulmak gerekiyor. Sadece zihinsel bir kavram olan bilgiyi teknik anlamda tanımlamak gerekirse, onu o yapan temel karakterin yanında bir de ait oldugu cinsi tespit etmek gerekecektir. Dolayısıyla bu daha zor olacaktır.

Bütün zorluklara rağmen, sadece zihinsel varlığı olan kavramları da tanımlamak zorunda oldugumuz açıktır. Çünkü bunlar tanımlanmadıkları zaman kavram kargaşasına yol açar ve insanlar arasındaki iletişimi bozarlar. ${ }^{2}$ İşte kelamcıların, başta bilgi olmak üzere soyut kavramları tanımlama gayretleri; üzerinde konuşulan kelamî problemlerde ortak bir dil oluşturup, iletişimi koruma çabasını içermektedir. Bu zorunluluk sebebiyle bunlar had anlamında bir tanımla tanımlanacaksa, mutlaka zihinsel bir kategori olarak cins ve tür belirlemeleri yapılmalıdır. Aksi takdirde yapılanlar ya eksik tanımlama olacaktır; ya da birer betimleme. Betimleme ise tanımlamanın daha alt bir derecesidir. Çeşitli betimlemeler arasından birini tercih etmek gerekirse, bu elbetteki onu benzerlerinden en iyi ayıran betim olacaktır. Din bilimlerinin çeşitli alanlarında soyut kavramlar için yapılan tanımların, bir tanım olmaktan daha çok birer resm/tasvir yani betimleme olduğunu söyleyebiliriz. Tek bir kavram üzerinde farklı tanımların ortaya konması ve genelde tanımlarda taksimin ve birden fazla niteliğin ifade edilmesi de yapılanların birer tanım olmaktan daha çok birer tasvir olduğunun göstergesidir.

\footnotetext{
Tanımlanamazlarla ilgili daha geniş bilgi için bkz., Necati Öner, Klasik Mantık, s.42.

İbrahim Emiroğlu, Ana Hatlarıyla Klasik Mantık, İstanbul 1999, s. 101-103.
} 
Gazzalî̀ye (ö.505/1111) kadarki dönemde soyut şeylerin tanımlanıp tanımlanmayacağı pek problem edinilmemiştir. Gazzalî'den itibaren bu mesele gündeme alınmış; hıem lehte hem de aleyhte görüşler ileri sürülmüştür. Gazzalî, cins ve faslını kapsayacak şekilde bilginin tanımını yapmanın zor olduğunu söyler. Çünkü bilgi sözcüğü müşterek bir kullanıma sahiptir. Bazen duyu algısı, bazen tahayyüller için, bazı zamanlarda zan, bazı zamanlarda aklın idrakleri için kullanılmaktadır ve bunlara göre tanımlamalar söz konusudur. Dollayısıyla bilgj ancak taksim ve misal yoluyla tanımlanabilir. Taksim, onu benzerlerinden ayıran ifadelerle tanımlamaktır. Misal ise, duyusal algllamava kıyasla iç görünün (basira el-batına) idrakidir. Göz bir şeyin nasıl ki kendisini değil de suretini alıyorsa, zihin de eşyanın suretini algılıyor. Bu tıpkı bir şeyin suretinin aynada görünmesi gibidir. Bilgi; aklın, ma'kulatın suretini almasından ibarettir. Taksim, bilginin benzerleriyle ilgisini keser; misal de bilginin hakikatini kavramayı sağlar. ${ }^{3}$

Râzî'nin (ö.606/1209). tanımlanabilen ve tanımlanamayanlarla ilgili yaklaşımı ise biraz daha farklıdır. $O$, hakikatleri basit ve mürekkep olmak üzere ikiye, bunları da başkasının varlığında yer tutan ve başkasının varlığında yer tutmayanlar clarak yine ikiye ayırır. Başkasının varlığında yer tutmayan basit hakikatler hem tanımlanamaz, hem de başka birini tanımlamazlar. Başkasının varlığında yer tutan basiı hakikatler tanımlanamaz ama tanımlarlar. Başkasının varlığında yer tutmayan mürekkep hakikatler tanımlanır, ama tanımlamazlar. Başkasının varlığında yer tutan mürekkep hakikatler ise hem tanımlanırlar, hem de tanımlarlar. ${ }^{4}$ Aynı görüşü benimseyen Beydâvî (ö.685/1236) bunu şöyle örneklendirir: Örneğin vacip kavramı birinci tip basit oldugundan ne tanımlanır, ne de tanımlayıcı olur. Cevher kavramı ikinci tip basit olduğından tanımlanamaz, ama tanımlayıcı olur. Insan kavramı birinci tip mürekkep olduğundan tanımlanır, ama tanımlamazlar. Hayvan kavramı ise ikinci tip mürekkep olduğundan dolayı hem tanımlanır, hem de tamılar. ${ }^{5}$ Dolayısıyla bir kavramı tanımlayabilmek ancak bunlardan tanımlanabilir bir hakikate tekabül ettiğini bulmakla mümkündür. Razî buna bağlı olarak, bilginin tanımını ne had ve ne de resm bakımından mümkün görür. Ona göre bilgi, tasavvuru apaçık olandır. Başkası onunla bilinir. Dolayısıyla onun kendisiyle bilineceğ başka bir şey yoktur. Eğer o da başkasıyla bilinseydi devr gerekirdi. Herkes kendi varlığını bedihî olarak bilir. Bilginin tasiıvuru bunun bir parçasıdır. Bedihî olanın cüzü bedihidir. $O$ halde bilginin tasavvuru bedihîdir. ${ }^{6}$

Taftazânî (ö.792/1390) de Razî gibi düşünür ve bilginin varlıktan önce ve öncelikle bedihî olduğunu, bilginin tasavvurunun başkasının tasavvuruna,

Gazzalî, el-Mustısfâ. Beyrut iy. s. 25-26.

4 Râzî, Muhassalu Efkâri'l-mütekaddimîn ve'l-müteahhirîn, thk. Taha A. Sa'd, Beyrut 1984, s. 29.

s Kadı Beydâvî, Tavâli'u'l-envâr. thk. Abbas Süleyman, Beyrut 1991, s. 59.

- Razî, Muhassal, s. 144-145; Razî, el-Mebahisu'l-meşriktyye, thk. Muhammed M. ElBağdâdî. Beyrut 1990, l, 450.453 . 
fakat başkasının tasavvurunun ise bilginin varlığına bağlı olduğunu söyleyerek bilginin tanımlanamayacağını ifade eder.? Çağımız İngiliz filozoflarından Jhon Cook Wilson (1849-1915) ile onun öğrencisi H. A. Pichard (1871-1947) da bilginin önce (primitive) olduğunu ve tanımlanamayacağını söylerler. Ayrıca Pichard bilgiyi üstün cins (sui generis) olarak görür ve tanımlanamayacağı kanaatini de taşır. ${ }^{8}$

Razî geleneğine bağlı kelamcılardan biri olan Seyfüddin el-Âmidî (ö.631/1233) ise bilginin cins ve fasl esasına uygun biçimde tanımlanabileceği kanaatini taşımakta ve tanımın buna uygun olduğunu iddia etmektedir. ${ }^{9}$

Bilginin tanımlanabileceğini ister kabul etsin isterse etmesinler, hemen hemen bütün kelamcılar, bilgiyi tanımlamaya çalışmış; ya da yapılan bir tanımı kabul etmişlerdir.

\section{Kelamcıların Bilgi Tanımları}

Kelamcıların yapmış oldukları bilgi tanımları, çeşitli özellikleri dikkate alınarak farklı şekillerde tasnif edilebilirler. Biz bilginin kendisiyle tanımlandığı temel kavramları dikkate alarak, bunların birbirine yakın olanlarını aynı başlık altında toplayıp üçlü bir tasnif yaptık. Bunlar; bilginin 1- bir tür itikat/inanç, 2- bir tür yeti ve 3- bir tür eylem/faaliyet olarak tanımlarıdır. Araştırmamızı bu tasnife göre üç başlık altında sürdüreceğiz.

\section{Bilginin Bir Tür İtikat/İnanç Olarak Tanımlanması}

Bilgi, Arapça'da ilim kavramıyla ifade edilir. Ancak ilim kavramı hem masdar olarak kullanılır ve her hangi bir zamanla ilişkili olmaksızın bilmek (to know) ya da bilme (knowing) eylemini gösterir, hem bu eylem sonucunda oluşan zihinsel bir varlık olan bilgiye (knowledge) isim olur; hem de belli bir esasa göre düzenlenmiş, sistemleştirilmiş bilgilerin adı olan bilime (science) delalet eder. Bizim burada üzerinde duracağımı ise, sadece bilgidir.

Bilginin tanımında kullanılan kavramlardan ilki itikat/inanç kavramıdır. Bilgiyi bir tür inanç olarak tanımlayanlar genelde Mutezilî kökenli kelamcılardır. Ebü'l-Hüzeyl el-Allaf'ın (ö.226/852) böyle tanımladığı anlatılır. Ama bu, "bilgi inançtır" şeklinde çok yalın bir tanımdır ve sadece cinsi ifade eder. ${ }^{10}$ Bu tanımın tanımlananı tam olarak ortaya koymadığına dair bir eleştiri yapılmıştır. Ebü'l-Hüzeyl'den sonraki Mutezilîler Allaf'ın tanımını, yapılan itirazı da göz önünde bulundurarak bir takım ilavelerle geliştirmişlerdir.

Ebü’l-Hüzeyl'den sonra Mutezilî kelamda bilgi, onun tanımına yapılan bir ilaveyle, "bir şeye olduğu gibi (alâ mâ hüve aleyh) inanmak (itikat)" diye

Taftazânî. Serhu'l-Makâsıd, (thk. Abdurrahman Umcyra), Beyrut 1989. I, 189.

Antony Quinton, "Knowledge and Belief", The Encyclopedia of Philosophy, New York 1967, London 1967, IV. 348.

9 Seyfüddin el-Âmidî, el-ihkâm fí usûli'l-ahkâm, Beyrut 1980, s.15.

10

Kadî Abdülcebbar, el-Muğnî, thk. İbrahim Medkûr, Kahire 1965, XII, 25. 
tanımlanmıştır. Bu tanım, Kadı Abdulcebbar (ö.425/1015) tarafından Ebû Ali el-Cübbâî (ö.303/915) ve Ebú Haşim el-Cübbâî́ye ye (ö.321/933) Sünnî kaynaklar tarafından ${ }^{12}$ da Ebüu'i-Kasım el-Belhî el-Kâ'bî'ye (ö.319/931) nispet edilir. Bu tanımda vurgulanmak istenen iki husus vardır: Bunlardan biri, bilginin bir çeşit inan: olduğudur ki itikat kavramı bunu ifade eder. Diğeri de bu inancın doğrulı̆̆udur ki; kenıdine inanılan şeyin inanıldı̆̆ı gibi olmasıyla, yani inancın şeye ya da olguya uygun olmasıyla kastedilen budur. Buradan hareketle bilginin doğru inanç olarak tanımlandığını söyleyebiliriz.

Bilgiyi doğru inaņ̧ olarak tanımlamak ne kadar doğrudur? Bu tanım, kapsamı açısından sağlıklı mıdır? Bu açılardan bakıldığında tanım, başta Mutezile'nin kendi içinde eleştirilmiştir." Mutezilî kelamcılar tarafından tanıma yapılan eleştiriyi Ebii'l-Muin en-Nesefí (ö.508/1114) şöyle nakleder: Eğer bilgi, "doğru inanç" clarak tanımlanırsa, halktan olan birisi, Allah'ın varlığına, peygamberin hak olduğuna ve àlemin yaratılmış olduğuna inanmaktadır ve onun bu inancı doğrudur. Peki bu durumda o bunları bilmekte midir? Bu soruya olumlu cevap vermek mümkün değildir. Çünkü, bu inanç o kimse açısından bilgi vasıtalarından biriyle elde edilmemiştir. Saydığımız bu inançlar, zıtların aynı anda aynı yerde bul.unamayacağı, üçüncü şıkkın imkânsızlığı ve parçanın büitünden küçük olacağı cinsinden aklın zorunlu bilgisi değildir. Duyularla elde edilen bir bilgi de olamazlar. Olsa olsa istidlalî yolla elde edilen bir bilgi olabilirler. Halktan olan birisi istidlal tekniğini bilemeyeceği için istidlal yapması söz konusu da olamaz. Dolayısıyla bu inanç ancak toplumdan alınmış olabilir. $O$ halde bu inancı bilgi olarak nitelemek mümkün cleğildir. ${ }^{14} \mathrm{Bu}$ eleştiri, bilgiyi sadece doğru inanç olarak tanımlamanın isabetli olmadığını gösterir. Mutezile'nin kendi içinden gelen bu eleştirinin amacı, doğru olsa da taklide dayanan inancın bilgi kapsamına girmesini engellemektir.

$\mathrm{Bu}$ eleştirinin mantıkî sağlaması ise şöyledir: Hatırlanacak olursa bu tanımda bilgi, "bir şeye olduğu gibi inanmak" idi ve biz bunu "bilgi doğru inançtır" şeklinde ifade etmiştik. Burada bilgi "itikat"ın bir türü olarak tanımlanmakta ve temel ayırıcı nitelik olarak da "doğruluk" gösterilmektedir. Buna göre, yanlış inanç da, bilginin zıttı olan "cehalet"i tanımlayacaktır. Dolayısıyla "cehalet, yanlış inançtır" dememiz gerekecektir. Tanımdan elde edeceğimiz "Her bilgi, doğru inançtır" küllî önermesini döndürürsek "Her doğru inanç, bilgidir" sonucunu elde ederiz. Bu durumda tanım, teknik açıdan yukarıda bahsedilen sorunu taşıyacaktır. Yani doğru bir inanç, bilgi vasıtalarından tiriyle elde edilmemiş olabileceği hâlde onu bilgi diye nitelemiş olacağız. Bu ise hatalı bir yaklașım olacaktır.

Kadî, Muğni, XII, 13.

Abdulkahir el-Bağdâdî, Usuliddin, İstanbul 1928, s. 5; Ebü'1-Muin Nesefî, Tabstratü'ledille, thk. Hüseyin Atay, Ankara 1993. s. 9.

13 Kadı, Muğnî, XII, 13.

14 Nesefí, Tabstra, s. 9. 
Mutezili'lerin bilgiyi itikat kavramıyla tanımlamaları, Sünnî kelamcılar tarafından en çok eleştirilen hususlardan biridir. Çünkü bilgiyi itikat/inanç olarak tanımlamak, bilenin mu'tekit/inanan olduğunu söylemek anlamına gelmektedir. Bunu Allah için düşündüğümüzde, O'nun için bilen demek inanan demek anlamına gelir. Böyle bir niteleme de Allah için mümkün değildir. O halde bilgi itikat kavramıyla tanımlanamaz. ${ }^{15}$ Ayrıca bilgi ile inanç bir kabul edilerek tersten bakılırsa şöyle bir sonuç çıkacaktır: Allah için inanan denmeyeceğine göre âlim de denmez. Bu da Allah'ın sıfatlarını reddetmek anlamına gelir. Nesefî böyle bir bakışı esas alarak, onların Allah'ın ilim sıfatını kabul etmemek için bilgiyi inanç olarak tanımladıkları ithamında bulunur. ${ }^{16}$ Biz onların, sırf Allah'ın ilmini kabul etmemek için böyle bir tanım yaptıklarını düşünmüyor, aksine bir mahiyet farkı gözeterek Allah'ın ilmini tanımın dışında bırakmayı hedeflemiş olabilecekleri kanaatini taşıyoruz. Zaten tanımlamaya çalıştıkları bilgi, beşerî bilgidir.

Mutezilîlerin tanımda itikat kavramını kullanmaları; Eş'an̂̀ (ö.324/935) ve Nesefî tarafından, dil yönünden de şu şekilde eleştirilmektedir: İtikat ve akd, aynı manadan türemiş iki lafızdır. Akd, cismin bazı cüzlerini diğer bazı cüzleriyle terkip ve cismi cisme ilave etmektir. Bu ise manalar arasinda gerçekleşmez. Öyleyse itikat lafzı bu hususta mecaz olarak kullanılmaktadır. Tanımda mecazî lafızları kullanmak ise tanımın yapılış amacına terstir."

Yapılan eleştiri öncelikle dil açısından bakıldığında doğru değildir. Çünkü, her ne kadar aralarında kök birliği olsa da bu iki kavram, aynı anlamı, yani cismin cüzlerini birbiriyle terkip etmck anlamını taşımaz. " $A k d$ " lafzı, Nesefî'nin işaret ettiği anlam dâhil olmak üzere çeşitli alanlardaki ve formlardaki sözleşmeleri içine alabilecek şekilde geniş bir anlam yelpazesine sahip olsa da, "itikat" lafzı dil açısından sadece, tasdik etmek, kalbini bir şeye manen bağlamak anlamı taşımaktadır. ${ }^{18}$ Yani Nesefî'nin dediği gibi "itikat" lafzı bu anlamda mecazî olarak kullanılmamakta, aksine bu, onun hakikî anlamı olmaktadır. Bu da zihinde karışıklık meydana getirir endişesiyle tanımda mecazî lafızların kullanılmayacağı ilkesini zedelemez. İkinci olarak "itikat" kavramı, Mutezilî düşüncede epistemolojik bir anlamda kullanılmakta ve zihinsel süreci ifade etmektedir. Buna göre bilgilerimiz ancak dikkat ettiğimizde fark edeceğimiz bir zihinsel süreçten geçmektedir. Bir şey hakkında duyumsama yaptığımızda ya da düşündügüumüzde, delilin kuvvetine göre cehalet, şüphe, tereddüt, zan veya bilgi gibi durumlardan biri oluşur. Bilgi durumu delillerin takviyesiyle itikadın kesinleşme durumudur. Buna göre itikat, cehaletten bilgiye uzanan durumların "ortak zihinsel

is Bağdâdî, Usul'iddin. s. 5; Nesefí. Tabsıra, s. 11.

16 Nesefi, a.g.e., s. 11-12.

17 İbn Fûrek, Mücerredü makâlâtiş'şeyh Ebi'l-Hasen el-Eş'arî, nşr. Daniel Gimaret, Beyrut 1987, s. 11; Nesefi, a.g.e., s. 12.

18 Sözlükte itikat, kesin olsun ya da olmasın, mutabık olsun ya da olmasın, sabit olsun ya da olmasın mutlak anlamda tasdik ve kalbin bir şeye bağlanması anlamına gelir. Bk. Butrus el-Bustânî. Muhitu'l-muhît, "itikad" md., Beyrut 1999. 
zemini" olmaktadır..$^{9}$ Dolayısıyla Nesefî'nin eleştirisinin, Mutezile'nin terimden anladıkları karşısında hiçbir geçerliliği yoktur.

Mutezili'lerin bilginin tanımında kullandıkları kavramlardan birisi de "şey" kavramıdır. Bu kavram da bazı Sünnî kelamcılar tarafından eleştirilmiştir. Îleride gösterecığimiz üzere bu yetersizliği gören Matüridî (ö.330/941) onun yerine mękûr kavramını, Bakıllanî ise ma'lum kavramını kullanmaktadır. Tanımda kullanılan "şey" kavramıyla ilgili olarak şöyle bir eleştiri yöneltilir: Varlık bilgiye konu olduğu gibi ma'dum/yokluk da bilgiye konu olur, ama yokluk "şey" değildir. Sïzgelimi Allah'ın eşi, benzeri, ortağı ve çocuğunun olmaması bilgimizin konusu olmaktadır ki kavramın kullanımı açısından bakıldığında bunlar "şey" değildir. Bu durumda, ya Hişam b. Amr'ın (ö.218/833) dediği gibi madumun/yokluğun bilinmediğini söylemek gerekir ki bu imkânsızờr, ya da "şey" kavramını tanımda kullanmamak gerekir. ${ }^{20}$

Bu eleştiri Ehl-i Sünnet görüşüne göre "şey" kavramının varlığı/mevcudu gösterdiğinden hareketle yapıldığında. ve Kâ'bî açısından bakıldığında isabetlidir. Çünkü o, şey kavramının mevcudu gösterdiği kanaatini taşımaktadır. ${ }^{21}$ Ama bu eleştiri, Bassa Mutezilîleri açısından bakıldığında isabetli değildir. Çünkü onlar, "şey" kavramını "ma'lum/bilinen" anlamında kullanmaktadırlar. ${ }^{22} \mathrm{Bu}$ durumda onların tanımda "sey" kavramını kullanmaları problem değildir. Bu onların, Matürîdî ve Bakıllanî (ö.403/1013) ile aynı şeyi söyledikleri anlamına gelir. Cüveynî (ö.478/185), Nesefî ve Îcî (ö.756/ 1355) ise, genel bir ifadeyle bu kavramın, Mutezile tarafından, varlığı mümkün olan madumu içine alabilecek şekilde kullanıldığını söylemektedirler. ${ }^{23}$ Mutezile içinde kimler tarafından söylendiği belli olmamakla birlikte, bu nispetin doğru olduğunu varsaydığımızda ise, varlığı mümkün olmayan madumu da bilme imkânımızclan dolayı "şey" kavramının kullanımı tanımda yeterli olmaz. Bu sebepten olacak ki Kadı Abdulcebbar, Ebû Haşim'e nisbet edilen tanımın aynısını yafmakla birlikte "şey" kavramının yerine "mutekad/inanılan" kavramını kullanmaktadır ${ }^{24}$ Dolayısıyla madum da tanımın içinde olabilecek şekilde ifacie edilmiş olmaktadır.

Mutezilîlerin bilgi bir :ieye olduğu gibi inanmaktır şeklindeki tanımları Ehl-i Sünnet tarafından her ne kadar bazı kavramlar yönünden eleştirilse de, form olarak bazı Sünnî kelamcılarca da benimsenmiştir. Eş'arîlerden Kadı Ebû Bekr Muhammed b. Tayyib el-Bâkıllâni, bilgiyi, "bilineni olduğu hal

19 Bunu şu şekilde göstermemiz l:onunun daha iyi anlaşılmasını sağlayacaktır:

gösteriyor)

Cehl Şek Zan Bilgi

Nesefi, Tabsira, s. 11; Gazzalî, Mustasfa, s. 25

Cüveynî, eş-Şâmil, thk. Helmut Klopfer, Kahire: 1y., s.35.

22 Cüveynî, a.g.e., s.34.

23 Cüvcynî, el-Irşad, thk. Esat Temim, Beyrut 1985, s. 34, Nesefí, a.g.e., s. 15, Adududdin el-Î́cî, el-Mevakıf, Beyrut ty., s.10.

24 Kadı Abdülcebbar, Şerhu Usuil'l-Hainse, Kahire 1988, s.46. 
üzere marifet etmek/tanımak" şeklinde tanımlamıştır. ${ }^{25}$ Cüveynî de el-İrşâd adlı eserinde Bakıllanî'nin bu tanımını benimseyip, bunun diğer tanımlardan daha isabetli olduğunu belirtir. ${ }^{26}$ Nesefí, Eş'añlerden bir başka kelamcının. marifet yerine idrak kavramını, yine Eş'arî kökenli olan Ebû İshak elİsferâinî'nin (ö.418/1027) ise, tebeyyün ${ }^{27}$ kavramını kullandıklarını nakleder ${ }^{28}$ ki, Îcî bunlardan birincisini ${ }^{29}$, Í bn Fûrek (ö.406/1015) de ikincisini Eş'arî’ye nisbet etmektedir. ${ }^{30}$ Bunlardan başka İbn Hazm (ö.456/1064) da yine aynı forma sadık kalarak bilgiyi, "bir şeyi olduğu gibi teyakkun etmek" diye tanımlamışırı. ${ }^{31}$ İki istisna dışta tutulursa bu tanımların aslında Mutezilî bilgi tanımı formunda olduğu açıkça görülür. Itikat yerine marifet, idrak, tebeyyün ve teyakkun; şey yerine de ma'lum terimleri kullanılmış, doğruluğu ifade eden olduğu gibi tabiri de aynen bırakılmıştır. Ancak bu tanımlara da kullanılan kavramlar açısından çeşitli itirazlar yapılmıştır.

Cüveynî, bilginin tebeyyün diye tanımlanmasını kapsamı yönünden eleştirir. İnsan daha önce bilmediği veya gaflet ettiği bir şeyi de tebeyyün ettim der. Bu durum kadîm bilgi için söz konusu olamaz. Dolayısıyla tanım onu içermemiş olur. ${ }^{32}$ Gazzalî, bilgiyi marifet diye tanımlamanın tanımların en zayıfı olduğunu söylemektedir. Çünkü bu türlü tanımlamalar lafzın müradifiyle yapılan totolojik tanımlardır. ${ }^{33}$ Tanımlarda kullanılan idrak ve tebeyyün kavramlarına Nesefî tarafından yöneltilen eleştiri ise, bu kavramların müşterek lafızlar olup, tanımda hangi anlamın kastedildiğinin net olarak bilinmemesidir. Bu durum, daha önce de belirttiğimiz gibi tanımın gayesi açısından sakıncalı bulunmaktadır ${ }^{34}$ Îcî ise, bilginin marifet olarak tanımının hem Allah'ın bilgisini dışarıda bıraktığını, hem de ancak bilgi

25 Bakıllanî, et-Temhid, thk. İmadüddin A. Haydar, Beyrut 1987, s. 25; Nesefî, Tabsıra, s. 13; Îcî, Mevakıf, s. 10.

26 Cüveynî, Irşad, s. 33. Bilgi konusunda farklı eserlerinde farklı tanımlar öne süren Cüveynî, es-Sâmil adlı cserinde ise, marifet lafzının yerine tebyîn lafłını kullanarak ve olduğu gibi ifadesini çıkararak bilgiyi "bilineni tebyîn (açıķ̧a ortaya f̧ıkarmalaçıkça ortaya çıkma), marifet ve istiykân (kesin olarak bilmek)" diye tanımlar ve 1 srarla bilginin özsel nitcliğinin "tebyîn" (açıkça ortaya çıkarma ya da açıkça ortaya çıkma) olduğunu söyler. Ona göre bilgide, kesinlikle şüphe ve kapalılık yoktur. Eğer bunlar varsa o, bilgi değildir. (bak. Cüveynî, Şamil, s.17).

27 Tebcyyün kavramını Taylan "aydınlanma" kavramıyla Türkçeleştirmek istemiştir. (Bkz. Necip Taylan, "Bilgi", DiA) Ama bunun çok da sağlıklı bir karşılık olduğunu düşünmüyorum. Çünkü aydınlanma kavramının Arapça karşılığı "tenevvür"dür. Tebeyyün ise, gizli olanın açığa çıkması ya da bir nedenle daha önce kavranmayanın kavranması anlamına gelmektedir. Epistemolojik bir düzlemde ele aldığımızdan ve kavram, bilgiyle ilgili olarak kullanıldığından ötürü biz ona "kavranma / açık hâle gelme" şeklinde Türkçe karşıllı verdik.

$2 s$ Nesefí, a.g.e., s. 14-15.

29 Îcî, a.g.e., s.10.

31) Ibn Fûrck, Mücerred, s.88, 89.

31 Ibon Hazm, el-Ihkâm fi Usuli'l-Ahkâm, Mısır 1978, s. 42.

32 Cüveynî, irşad, s.33.

33 Gazzalî, Mustasfâ, s. 24.

34 Nescfi, Tabsira, s. 14, 15. 
bilindikten sonra malum bilineceğinden ötïrü tanımda devr olduğunu söyler. Idrak lafzının ise ilim sözciiğünden mecaz olduğunu söyleyerek tanımda devr olduğunu belirtir. Bu yiizden bilgiyi idrak lafzıyla tanımlamayı doğru bulmaz. ${ }^{35}$ Bu eleştiriler birlestirildiğinde bunların a) eş anlamlı kelimelerle yapılmış lafzî tanımlar, b) mecâzî veya müşterek sözler olduğu ve c) bu tür tanımların Allah'ın bilgisini dışarda bıraktığıdır.

Gazzalî’nin eleştirisi marifetle bilgiyi eş anlamlı gördüğü için tutarlıdır. Çünkü buna göre bilgiyi marifetle tanımlarnak, ona yeni bir anlam katmaz. Halbuki tanımlar tanımlanana yeni bir anlam katmalıdırlar. Marifetin bilgiyle eş anlamlı değil de onun bir türï olduğunu söylersek Gazzalî'nin eleştirisi de isabetli olmaktain çıkar. Çünküi bu durumda bilgi kapsamından bir kısmıyla tanımlanmış olur ve kapsamı problemli hale gelir. Îcî'nin tanıma yönelttiği eleştiri ise: isabetsiz göziukmektedir. Çünkü tanımlanan, insanın bilgisidir. Allah'ın bilgisinin insan bi gisine benzemediğini Îcî de teorik olarak kabul etmektedir. Dolayısıyla benzemeyenleri aynı tanım altında toplamak isabetli görünmemektedir.

Burada marifet bilginin aynı mıdır, yoksa kapsamı dâhilinde olup onun bir cüzünü veya bir türünü mü teşkil etmektedir? sorusu önem arzetmektedir. Dolayısıyla önce bunun çc̈zümlemesi yapılmalıdır. Marifet kavramının tanımda kullanılmaması gerєktiğini öne sürenler, bu kavramın Allah'a izafe edilmiş şeklinin Kur'an'da ya da Arap dilinde kullanılmamasını öne sürerler. Buna göre Allah'a alime-ya'lemu/bilir fiili izafe edilir ve o fiilden türeyen alim/alîm/bilen sıfatlarıla nitelenir, ama arafe-ya'rifu fiili izafe edilmez ve Allah ârif olarak da nitelenmıez. Dolayısıyla Allah, âlim olup ârif olmadığına göre bilgi de marifet olamaz. ${ }^{36}$ Görüldüğü üzere kavramla ilgili olarak yapılan bu eleştiri episternolojik değil, dinî yöndendir. Fakat marifet kavramının dildeki kullanımları göz önüne alındığında, onun bir taraftan tanımanın, diğer taraftan tecrïbeye dayalı bilgi birikiminin adı olduğu görülür. Dolayısıyla bilgi yalnızca marifet olarak tanımlanamaz. Marifetin tanımaya dayalı bilgi olduğuna, Ehl-i Kitab'in Hz. Peygamber'i oğullarını tanıdıkları gibi tanıdıklarmı fakat ona iman etmediklerini anlatan ayet (Bakara, 2/146) delalet eder. Arap dilindeki, alime ve arafe fiillerinin kullanım farklılıklarından da bunu çıarabiliriz. Arafe fertleri bilmekle ilgili olarak kullanılırken alime fertlerle ilgili hükümleri bilmekle ilgili kullanılır. ${ }^{37}$ İslâm mantıkçıları da bu ay rımı esas alarak bilgiyi tasavvur ve tasdik diye ikiye ayırmışlardır. Onlar nüfretleri bilmeyi tasavvur, müfretler arasındaki haberi nispetleri bilmeyi ise tasdik diye isimlendirirler. Bazı âlimler bunlardan birincisinin marifet, ikincisinin de ilim olduğunu söylerler. Bunda dilcilerin, marifetin bir mef'ul, zannın ise jki mef'ul aldığına ve ilmin de zan grubundan olduğuna dair tesbitlerine dayanırlar. ${ }^{38}$

\footnotetext{
Îcî, Mevakıf, s.10.

Nesefi, a.g.e., s. 13.

Nescfi, a.g.e., s. 14.

Gazzalî, Mustasfâ, s. 11
} 
Nesefî'nin idrak ve tebeyyün kavramlarının tanımda kullanılmasına yaptığı itirazın dayanağ $\breve{g}_{1}$ sudur: Arap dilinde insan bir şeyi anladığında "idrak etti" denilir, bir şeye yetiştiğinde "idrak etti" denilir, bir şeyi bütünüyle kavradığında da "idrak etti" denilir. Tanımda kullanılan idrak kavramından bu anlamların hangisinin kastedildiği belli değildir. Tebeyyün de böyledir. "Tebeyyentü'l-emra" bildim anlamına gelirken "tebeyyene lî" açık olmak, zuhur etmek anlamina gelmektedir. Kastedilen bunlardan hangisidir? ${ }^{39}$ Tebeyyün ile ilgili kullanıma dikkat edilirse, birinci kullanımda doğrudan tümleç aldığı, ikinci kullanımda ise harf-i cer aldığı görülür. Bu durum; bir anlam farklılaşması meydana getirdiği için, yalın biçimde kullanıldı̆̆ında bir şeyi kavramak anlamına gelir ve bir anlam kargaşasına yol açmaz. İdrak kavramında da durum böyledir. Tümlecine göre hangi anlamın kastedildiği açıkça bilinir. Matüridî'nin tanımda kullandığı yetecellâ/yenceli kavramı, Nesefî her ne kadar eleştirmese de, aslında bunlar gibi müşterek bir sözdür ve tanımın gayesi açısından bakıldı̆̆ında onun için de aynı şeyi söylememiz mümkündür. Zira tecellî zuhur etmek, ortaya çımak anlamına geldiği gibi, bir şeye yönelerek bakmak anlamına da gelir.

Bu tanımlardan hareketle bilginin bilinenin olduğu gibi kavranması, şeklinde ortak bir tanım üretirsek, buradan "her bilgi, bilinenin olduğu gibi kavranmasıdır" küllî önermesine ulaşırız. Bunu döndürdügüumüzde ise, "bilinenin olduğu gibi her kavranması da bilgidir" sonucuna ulaşırız. Bu da doğrudur. Aks ve tard açısından bir problem gözükmemektedir. Ancak bunlar birer lafzî tanımdan öteye geçmezler. Bu da bilginin ne olduğunu ortaya koymaz, sadece dildeki anlamının ne olduğunu açıklar.

Sünnî kelamcılar bilgiyi itikat/inanç terimiyle tanımlamayı doğru bulmazlar, ama bilginin zıttı olan cehl kavramı için aynı şeyi düşünmezler. Sözgelimi Cüveynî, itikat kavramını bilginin tanımlanmasında kullanmaktan kaçınırken, onun zıttı olan cehil kavramının tanımında bu kavramı kullanmaktadır. O, cehli "bir şeye, olduğu durumun aksine olan inanģ" diye tanımlamaktadır. ${ }^{4)}$ Yani buna göre cehl, yanlış inançtır. Bu, her halde Mutezilî düşünceden kaçarken ona tutunmanın göstergesidir.

Bilginin ne olduğunu bölümleme yoluyla analiz eden Gazzalî de, bilgiyle itikat arasında kesinlik yönünden benzerlik olduğundan ve bu yüzden bu ikisinin arasını ayırmada insanın zorlandığından hareketle yaptığı açıklamada bilgiyi bir itikat türü olarak gördügüüün ipuçlarını verir:

"Bilginin, kudret ve irade gibi nefsanî sıfatlardan farklılığı açıktır, bunlarla karışmaz. Şek ve zanla da farklılı̆̆ı açıktır, çünkü bunlarda kesinlik yoktur, bilgide ise kesinlik vardır. Bilgi cehl ile de karı̧̧maz, çünkü cehl, bir şeyi olduğu gibi bilmemektir. Bilgi ise vakıaya mutabıktır. Bilgi sadece, mukallidin basiretle değil de takliden elde ettiği, bir şeyin öyle olduğuna dair kesin ve doğru inancıyla karışır... İtikat mukallit için söz konusudur bilen için değil. Mukallit, bir şeye, olduğunun hılafına olacak şekilde,

39) Nesefi, Tabsira, s. 14, 15.

4) Cüveynî, irşad, s. 27, 35 . 
bilmeden kesin olarak inanabileceği gibi; sırf telkin ve taklit yoluyla zıddına ihtimal vermeyecek şekilde kısin ve vakıa mutabık olarak da inanabilir. İşte itikatla bilginin ayrıldığı nokta burasıdır. Jtik:tdın anlamı; şüpheye düşen birinin inanılacak iki durumdan birini, diğerine ihtimal vermeyecek ve kesin bir kanaate sahip olacak şekilde tercih etmesidir. Ömeğin şüpheye düşen 'kimse âlemin kadîm mi yoks. $ı$ hâdîs mi oldığg hususunda kesin bir kanaate sahip olamaz. İtikat eden, âlemin hâdîs olduğuna, bunun zıddına ihtimal vermeyecek şekilde inanır. C'ahil ise âlemin kadîm olduğunu söyler. İtikat vakıa mutabık olsa bile bir revi bilgisizlikıir (cehl). Zeydin evde olduğuna inanan kimsenin inancı Zeyd'in evden çıktığımı farzetsek bile devam eder. Ama bilgi bilinenin değişmesiyle değişir. Bilgi keşf ve inkişaftır, itikat ise kalpte ukdedir. Bilgi bu ukdeyi çözmektir."

Gazzalî her ne kadar Mutezilî bilgi tanımını eleştirse de verdiği örnekten anlaşıldığına göre aslında bilmekle inanmanın kesinlik ve doğruluk vasfında birleştiğini, elde ediliş biçiminde ise farklılaştığını söylemiş olmaktadır. Dolayısıyla onun da bilgiyi basiretle. elde edilmiş kesin ve doğru bir inanç olarak tanımladığırı söyleyebiliriz. Ayrıca metinde geçtiği üzere o, aynen Cüveynî gibi bilginin zıttı olan cehli bir inanç kategorisi olarak tanımlamaktadır. Cehl bir inanç kategorisi ise, onun zıttı olan bilgi neden aynı kategoride yer almasın?

Nesefî'nin bilgide bir sübjektif yön olduğuna dair dile getirdiği kanaatleri -biz onlara biraz sonra değine:ce ̧̧̧iz- de onun bilgiyi bir inanç türü olarak algıladığı düşüncesini çağriş̧ırmakta.dır. Bunlardan hareketle Mutezilî tanımı kabul etmeyen Sünnî kelamcıların meseleleri mütalaa ederken biraz tepkisel bir yaklaşım sergilediklerini söyleyebiliriz. Fakat Sünnî kökenli kelamcılardan bilginin bir itikat türü olduğunu açıkça kabul edenler de vardır. Örneğin Razî inanł̧ları tanımlarken bu konuya şöyle bir açıklık getirmektedir:

"Ínançlar insanın nefsinde bulduğu ve onu başkalarından zorunlu olarak ayırdığı şeylerdir. İnançlar ya kesin, ya da tereddütlü olur. Kesin olanlar mutabık olmazlarsa cehl adını alırlar. Mutabık olurlarsa, ya bir vasıtaya dayanmaksızın olur ki bu, taklit adını alır, ya da bir vasıtaya dayalı olarak olur ki bu da bedihiyyat, zanniyyat ve nazariyyat adını alır."42

İktibas ettiğimiz metin de görüldüğü üzere aslında Razî bilgiyi bir inanç kategorisi olarak düşünmekte ve onu bir vasıtaya dayalı olarak elde edilmiş vakıa mutabık inanç olarak tanımlamaktadır. ${ }^{33}$ Râzî tasdik hakkında da aynı yaklaşımı sergilemektedir. Tasdiki kesin olan ve kesin olmayan diye ikiye ayıran Razî; kesin olmayan tasdiklerin şek ve zan içerdiğini, kesin olanların da vakıaya mutabık olan ve olmayan diye ikiye ayrıldığını söylemektedir.

Gazzalî, Mustasfâ, s. 25-26.

42 Razî. Muhassal, s. 144-145.

43 Îcî, Razî'nin bilgiyi varlığa mutabık kesin inanç olarak tanımladığını söyler (bk. Îcî, Mevakıf, s.10.) ama bu ibare onun tanımını akıarmak bakımından yeterli değildir. Çünkü Razî vasıtaya da vurgu yapmikktadır. 
Mutabık olmayanlar cehalet/bilgisizlik içerir. Mutabık olanlar da bir kaynağa dayalı olanlar ve bir kaynağa dayalı olmayanlar diye ikiye ayrılır. Bir kaynağa dayalı olmayanlar zan; aklî, hissî ya da hem aklî hem de hissî bir kaynağa dayalı olanlar da bilgi içerirler demektedir. ${ }^{44}$ Her ne kadar bilginin tanımlanamayacağını söylese de, Razî’nin tasdik hakkındaki bu açıklamasından da anlaşıldığı gibi o, bilgiyi belli kaynaklara dayanan vakıaya mutabık inanç olarak görmektedir.

Mutezilîlerin bilgiyi doğru inanç olarak tanımlamalarının Mutezile içinde eleştirildiğinden daha önce bahsetmiştik. Ancak bu sadece bir eleştiri olarak kalmamış; tanımdaki kusur yine kendileri tarafından giderilmeye çalışılmıştır. Sünnî kaynaklar Ebû Ali el-Cübbâî'nin bu eleştiriyi gidermek amaciyla zorunlu olarak ya da delile dayanarak şeklinde bir ilavede bulunduğunu naklederler. ${ }^{45}$ Buna göre o, temelde bilginin bir şeye olduğu gibi inanmak olduğunu kabul eder. Ama tanıma yapılan ilk eleştiriye muhatap olmamak için bu inancın, "zorunlu" ya da "istidlall̂" bir inanç olmasını şart koşar. Bir şeyin zorunlu olarak bilinmesi kendinden kanıtlı olmasından; istidlalî olarak bilinmesi de aklî çıkarımdan kaynaklanır. Bize göre $o$, bu ilave sözlerle tanımdaki eksikliği gidermiş olmaktadır. Çünkü tanımda, kişide meydana gelen inanç, bilginin kaynaklarına (yani, bir şeye olduğu hâl üzere olan inancın kişide oluşması akla, duyulara ya da istidlale) dayandırılmaktadır. Bunlara dayanmayan bir inanç doğru da olsa bilgi kapsamına girmemektedir. Bu da bilginin, "kantta dayalı doğru inanç" olduğu anlamına gelmektedir. Bu ilavelerle bir şey hakkındaki taklidî inanç, kanıta dayanmadığı için bilginin kapsamı dışında bırakılmış olmaktadır. Her bilginin zorunlu ya da istidlalî yolla elde edilen doğru inanç olduğunu söylersek, bunun in'ikasında, her zorunlu ya da istidlalî yolla elde edilen doğru inancın bilgi olduğunu da söylememiz gerekir ki bu, doğru bir tanımlama olmuş olur.

Ebû Ali el-Cübbaî'nin, "zorunlu ya da istidlâlî olarak itikat etmek" ilavesiyle -ki biz bunu "kanta dayalı" şeklinde ifade etmiştik- tanımı tamamlamaya çalışması bilginin nasıl elde edildiğini ortaya koymak bakımından anlamlıdır, fakat onun "kaynağı", onu zandan ve doğru itikattan ayıran özsel nitelik olamaz. Dolayısıyla bunun teknik anlamda tam bir tanımdan ziyade eksik bir tanım olduğunu söyleyebiliriz. Zaten onun öze yönelik bir tanım yapma gayreti yoktur. Bu, daha önce bahsettiğimiz gibi Cübbâî'nin tanımla ilgili görüşleriyle uyum içindedir.

Ancak Nesefî tanımı, bu ilavelerle tanımdan ziyade taksim yapıldığı, taksimin ise tanım tekniği bakımından uygun bir form olmadığı yönünde eleştirmiştir. Nesefî şöyle der:

"Herhangi bir bilgi hem zarurî, hem de istidlalî olmaz. Zarurî olan bilgiler istidlalî olmaz, istidlalî olanlar da zarurî olmaz. Bir şeyi zarurî olarak olduğu hâl üzere itikat etmek bilgi olursa, -ki bilgi, bir şeyi zarurî

4 Razî, Mebahis, I, 464.

45 Bặdâdî. Usuliddin, s. 5; Nescfí. Tabsıra, s. 10. 
olarak olduğu hâl üzere itikat etmektir denmişti- istidlali bilgi tanımın dışında kaldığı için bilgi olme.z. Tanımın dışında kalmakla birlikte onun bilgi olduğu kabul edilirse, tanım cazim olmaktan çıktığ (kapsamını yitirdiği) için batıl olur. İstidlalî bilgi için de: durum aynıdır.",

Kanaatimizce bu yerinde bir eleştiri değildir, zira Cübbâî'nin yaptığı taksim, bilginin cins kabul edilip türlerinin belirlenmesi anlamında kategorik bir taksim olmayıp, kaynaklarının ya da kanıtlarının belirlendiği bir taksimdir. Dolayısıyla bu tc.ksim tanıma, Nesefî'nin belirttiği türden bir eksiklik getirmez. Ayrıca bilģinin had anlamındaki tanımından değil de resm anlamındaki tanımından bahsediyorsak, onun bu tanımı kanaatimizce bilgiyi tanımlamada yeterlidir.

Ebû Ali el-Cübbâî'nin tanıma ilave etliğgi bu ifadeler, temel bir soruna daha kapı açmaktadır. Onun zorunlu ve istidlalî olmayı dile getirip de, haberi bilgi kaynakları arasında zikretmemesi, Mutezilìlerin nazarında haberin bilgi kaynağı olarak kabul edilmediği düşüncesini çağrıştırmaktadır. Bunlardan hareketle onların haberi, bilgi vasıtası olarak kabul etmediği sonucuna varabilir miyiz? Buna olumlu cevap vermek elbette mümkün değildir. Öncelikle onların, bu konuda açıkça söylenmiş olumsuz bir hükümleri yoktur. Bilgi sistemleri içincle haberi kullanmaları ise, bilgi kaynağı olarak kabul ettikleri anlamına gelir. O halde Cübbâî haberi neden bilgi kaynakları arasında zikretmemiş olabilir? Buna cevap olarak, onların haberi müstakil bir kaynak değil, bir kısmını zorunlu, digger bir kısmını da istidlalî bilgi içinde bir tür olarak gördükle rini söyleyebilijiz.

Bilginin bir şeye olduğ,u gibi inanmak şeklindeki tanımına bir başka düzeltme de son dönem Mutezile kelamcısı Kadı Abdulcebbar'dan gelmektedir. O, bilgiyi seleflerinden biraz daha farklı bir biçimde, "bilenin bildiğ $i$ şeyde nefsini mutmain eden anlam ${ }^{\prime 47}$ diye tanımlamakta ve kişiyi inandığı şeyin doğru olduģ,unda bir şüphe duymayacak kadar kesin bir kanaate sahip eden bu ınanânın bilginin ayırıcı özelliği olduğunu vurgulamakta, ayrıca bu mianânın, doğruluğu özel bir şekilde elde edilen inanç olduğunu da belirtmektedir. Yani orı göre bu manâ, özel bir surette elde edilen ve kişide kesinliği meydana getiren doğru inançtır. Bunu bir diğer eserinde doğrudan itikat kavramıyla "bilgi inandı ğının (mutekad/inanç nesnesi) inandığı gibi olduğuna nefsin mutmain olduğu (teskunu bihi ennefsu) itikat" diye tanımlannıştır. ${ }^{48}$ Yalnız, birincisinde bilginin etkinliği öne çıkarılırken, ikincisinde, bu etkinlik vurgusu kaybolmaktadır. Kadı Abdülcebbar'ın bilginin ayırıcı temel niteliği olarak ortaya koyduğu bu vasıfla birlikte bilgi tanımında üç adet vasıf söylenmiş oldu: Bunlar, doğruluk,

th Nesefí, Tabsira, s. 10.

$47 \mathrm{Kad}_{1}$, Muğnî, XII, 13

4 Kadı, Serh, s.46. Bu tanım. Nesefí tarafından ufak bir lafız farkıyla Ebû Haşim elCübbâî̀ye de nisbet edilmişıir. Ebû Haşim'e nisbet edilen bu tanım, "nefsin kanaat getirmesiyle (sükûnu'n-nefs) neraber bir şeyin olduğu hâl ü̈̈ere inikadıdır" şeklindedir. Ncsefi, Tabsira, s. 9. 
kanıta dayalı olmak ve kesinliktir. Acaba bunlardan hangisi temel ayırıcı niteliktir? Cübbâilerin temel vasıf arama gibi bir gayretleri yoktur, ama Kadı Abdülcebbar açısından bakacak olursak o açıkça temel nitelikten bahsediyor. Ama onun ortaya koyduğu niteliği temel nitelik olarak görmemiz, pek de doğru olmasa gerektir. Zira bu, ancak onun kendisinde olduğu kimsede meydana getirdiği etkiyi gösterir. Bu da tıpkı siyahlığın üzerinde bulunduğu cismi siyah yapması gibidir. Siyah yapma siyahlığı tanımlamadığı gibi, kesin kanaat meydana getirme de bilgiyi tanimlamaz.

Biz Kadı Abdülcebbar'ın ifadelerinden hareketle bilginin, "kesin bir kanaat veren/ içeren doğru inanç" olarak tanımlandığını söyleyebiliriz. Onun tanıma böyle bir ilavede bulunması, yukarıda dile getirdiğimiz, bilginin doğru inanç olarak tanımına yapılan itirazı gidermek amacını taşımamakta, aksine o bununla bilgi tanımlarında gördüğü bir eksikliği gidermeyi amaçlamaktadır. Bu da bilginin yapısında şüphe ve tereddüt cinsinden her hangi bir şey olmayıp, kesinlik vasfına sahip olması gerektiğidir. $O$ her ne kadar tanımında kişide kesinliği sağlayan inancın vasıtalarına dair bir sözcük kullanmasa da, tanımı açıklarken bu inancın özel bir surette elde edildiğini söyleyerek bu eksikliği gidermektedir. Buradan hareketle bu inancın elde ediliş biçiminin onun için bir ön kabul olduğunu söyleyebiliriz. Ama bunu ifade edecek sözcüğün doğrudan tanıma konması daha isabetli olurdu. Zira sadece tanımda kullanılan kavramlardan hareketle bir sonuca ulaşılacak olursa, bu hususun gözden kaçırıldığını düşünmek mümkün olacaktır. Yine buradan hareketle aks tard yapacak olursak, her bilginin kesin bir kanaat duyulan doğru inanç olduğunu söylediğimizde bunun döndürülmesi olan kesin bir kanaat duyulan her doğru inanç bilgidir tümel önermesinin de doğru olması gerekir. Halbuki subjektif kesinlik içeren doğru inançlar vardır ve bu inançlar taklit yoluyla kazanılmış veya kesin olmayan delillerden elde edilmiş olabileceğinden, bilgi olarak adlandıramayız.

Bilginin kesin bir kanaat içeren doğru inanç olarak tanımlanması başka bir probleme daha kapı açacaktır. Burada doğru inaņ̧ olan bilginin temel ayırıcı özelliği kişide kesin bir kanaat oluşturması olarak gösterilmektedir. ${ }^{49}$ Bu durumda kişide kesin kanaat oluşturmayan inanç doğru da olsa bilgi olmayacaktır. Bu anlayış, katı akılcılığın ifadesi olan, bilginin herkes için kesin bir kanaat oluşturacağına dair bir düşünceyi de beraberinde getirecektir. Aksi takdirde bilgide tam bir görecelik oldugunu kabul etmek gerekir. Yani bir bilgi nesnesi hakkında, onun inandığı gibi olduğuna kesin bir kanaat duyan kimse için bu inanç bilgi olurken, aynı şekilde bir kanaat duymayan için bilgi olmayacaktır. Her ne kadar Mutezilî bilgi tanımın kabul etmeseler de, bilgide izafî bir yön olduğunu bazı Sünnî kelamcılar da kabul etmektedirler. Örneğin mütevatir haberin bilgi değeri ile ilgili olarak Nesef̂́'nin söylediği şu sözler bunun açık bir göstergesidir:

sy Kadı, a.g.e., s.46; Muğnî, XII, 13, 25, 30. 
"Farklı zamanlarda farklı yerlerden gelen on, yirmi veya daha fazla sayıdaki kimsenin verdiği bir haberi işiten iki kişiden birinin kalbi, bunların bir araya gelemeyecekleri düşüncesiyle bu habere mutmain ve diğerinin kalbi de, bunların bir araya gelmiş olabilecekleri düşüncesiyle tereddütte olsa, bunlardan birincisi bilgiy i elde etmiş, ikincisi elde etmemiş olur."

Nesefî aynı şeyi istidlalí bilgi hakkında da söylemektedir. Bir peygamberin mucizesine bakarak, kesin bir kanaatle onun peygamberliğine hükmeden için bilgi sabit olurkın, bunda tereddüt eden kimse için bilgi sabit olmaz. Çünkü birincisinde bilginin zıttı olan şüphe yok iken, ikincisinde şüphe vardır..$^{51}$ Buradan hareketle Nesefî'nin bilgi kaynaklarının insana sunduğu verilerin onda mutlak bir kesinlik meydana getirmediği, kişinin zihnî durumunun bunda etkili olduğu görüşünde olduğunu, bu sebeple izafîliğ kişilerde gördügünü söyleyebiliriz.

Bilginin kişide kesin kanaat oluşturmasını önemli gören Kadı Abdülcebbar kesinliğin kaynağını nerede görmektedir? Bunun kaynağı salt kişi midir, yoksa bilgi vasitaları midır? Onun "Zeydin evde olduğuna, onu evde görerek inanmakla, insanlardan birinin haberine binaen inanmak arasında fark vardır. Çünkü kişi bunlardan birincide bulduğu özelliğ $i$ diğerinde bulamaz" ${ }^{2}$ sözü bu konuda bize bir ipucu verebilecek niteliktedir. Çünkü onun, duyumsama ile haberin süjede oluşıurduğu güven farklılığına dikkat çeken bu sözü, habere dayarıan bilginin insan zihninde bir kesinlik meydana getirmediğini imâ etmektedir. Yani bilginin kaynăğ kesin kanaat oluşturuyorsa bilgi kesiri, oluştuımuyorsa bilgi kesin değildir. Buradan hareketle onun, insanda kesin kanaat oluşmasının, zihinle değil, bilginin vasıtalarıyla ilgili bir durum olduğu inarıcını taşıdığını söyleyebiliriz. Bu durumda aynı veriler karşısında bütün zihinlerin aynı tepkiyj duyacağ eşitliği iddia edilmiş olur ki, bu tartışılabilir bir husustur.

Kadı Abdülcebbar'ın raberin insanda oluşturduğu güvenin derecesine işaret eden bu sözleri aslında istidlalin oluşturduğu güvenle ilgili bir eleştiri olarak kabul edilmelidir. Çünkü ona göre verilen bir haberle ilgili olarak insan zihni, hemen haberin kaynağının güvenilirliğine bakmakta ve haber verenin doğruluğundan hareketle haberin doğruluğuna intikal etmektedir. Bunun ilk adımı olarak da haber verenin güvenilirliğini ortaya koyacak bir emâre araştırmaktadır. ${ }^{53} \mathrm{Bu}$ da aslında bi: nevi istidlaldir ve bununla elde edilen bilgi de, istidlalî bilgi olmalıdır. Y'ani kaynak, haber olsa da, insan zihni hemen bir istidlal yaparak o haberi ya kabul eder ya reddeder. Aslinda bu, duyuların bazı doğrudan algıları için de söz konusudur. Örneğin güneşin küçük olduğunu görürüz, ama büyük olduğuna hükmederiz. Bu hükmü verirken yaptığımız şey, yine bir istidlaldir. Yalnız, Kadı Abdulcebbar haberi, doğruluğu zorunlu clarak bilinen ve istidlalî olarak bilinen diye ikiye

\footnotetext{
Nesefi. Tabsira, s. 54-55.

Nesefi, a.g.e., s. 55

Kad, Şerh. s.47.

Kadî, Muğnî, XII. 26.
} 
ayırmaktadır. Bunlar mütevatir haberler ve Allah'ın varlığını, birliğini; $\mathrm{Hz}$. Peygamberin nübüvvetini bilmek gibi aklî konulardaki haberlerdir. Bir de doğruluğu ne zorunlu olarak, ne de istidlalî olarak bilinebilecek haberler vardır ki bunlar âhad haberler olup, inanç konularında delil olmazlar demektedir. ${ }^{54}$ Onun bu ayrımı, eleştirisinin, kesin kanaat oluşturma yönünden haberin her türüne yöneltilmiş bir eleştiri olmadığını da ortaya koyar. Haberin bir kısmını zorunlu, diğer bir kısmını da istidlalî bilgiyle ilişkilendirerek yapılan bu ayrım, Cübbâî'nin görüşlerini incelerken Mutezilîlerin haberi bilgi vasıtası olarak gördüklerine dair yaptığımız çıkarımı da desteklemektedir.

Haberi bu şekilde bir bilgi kaynağı olarak algılamak Sünnî kelamı açısından da yadsınacak bir durum değildir. Sözgelimi Bakıllânî sadece mütevatir haberi zorunlu bilginin kaynakları arasında zikrediyor ve bunun dışında kalan haberi bilgi kaynakları arasında zikretmiyor. ${ }^{55}$ Razî de tasdik hakkındaki incelemesinde sadece mütevatir haberi, vakıaya mutabık kesin tasdikin hem hissî, hem de aklî kaynaklarından biri olarak görür. ${ }^{56}$

\section{Bilginin Bir Tür Yeti Olarak Tanımlanması}

Bilgiyi bir tür yeti olarak tanımlayan kelamcılar, Ehl-i Sünnet'in iki büyük kelamcısı Eş'arî ile Matürîdî ve bunların bazı takipçileridir. Bilgiyi yeti olarak tanımlayan kelamcılar tanımlarında sıfat kavramını kullanırlar. Sıfat dilde özne ya da nesneyi niteleyen kavramdır. Varlıkta ise ya bir yetiyi, ya da bir durumu ifade eder. İçlerinde sıfat kavramı geçen tanımlarda ise, şimdi inceleyeceğimiz üzere, yeti anlamında kullanılmıştır.

Eş'an'tnin bilgiyi, "bilenin bilineni kendisiyle bildiğgi şey" 57 , "kendisinde olduğu kimseyi bilen yapan şey"s8 ya da "kendisinde olduğu kimseye bilen vasfint veren sıfat" veya "kendisinde olduğu kimseyi bilen yapan vasıf" 59 diye tanımladığı rivayet edilmektedir. Bu tanımların hepsi de ibarelerdeki küçük farklılıklara rağmen aynı şeyi söylemektedirler. Ilk iki tanımdaki "şey" lafzı bir cevher varlığı göstermez, sadece sıfat kavramının karşılığıdır. Hem diğer iki tanımda bilginin bir sıfat olduğu açıkça ifade edilmekte, hem de yine Eş'arî'nin, "Kişi hareket, kudret, renk, tat gibi niteliklerle bilen olmaz, bilgiyle bilen olur" sözünde bilginin bir sifat olduğu vurgulanmaktadır. ${ }^{60}$ Onun burada saydığ 1 şeyler bir takım sıfatlardır. Birinci tanımda bilginin bilenle bilinen arasındaki zihinsel ilişkiyi sağlayan sıfat olması açık biç̧imde ifade edildiği için diğer üç tanımdan daha sorunsuzdur. Diğer üçünde ise bilgi, bilinenden ilgisiz biçimde bilene ait bir sıfat olarak

\footnotetext{
Kadi, Serh, s.768-770.

Bâkıllânî, Temhid, s. 30.

Razî, Mebahis, I, 464.

İbn Fûrek, Mücerred, s.10.

Cüveynî, Irşad, s. 33.

Nesefí, Tabsıra, s. 15; Îcî, Mevakıf, s.10.

İbn Fûrek, Mücerred, s.10.
} 
anlatılmıştır. Cüveynî el-Kâfiye fi'l-cedel adlı kitabında el-Irşâd'dakinin aksine, bizim Eş'arî'nin tanımları arasında ilk sırada verdiğimiz; bilgi bilinenin kendisiyle bilindiği şeydir şeklindeki tanımı kabul eder ve bunun bilgiyi bilgi olmayanlardan ayıran tam bir tanım olduğunu söyler. ${ }^{61}$

Eş'arî, ilim, marifet, fehm, fitnat, dirayet, akıl ve fıkh kavramları arasında her hangi bir farklılık da görmez. Ona göre bunların hepsi bilmek anlamındadır. Ama Allah bunlardan ancak ilim kavramıla vasıflanabilir. Bu da O'nun kendisini diğger kavramlarla değil de ilimle nitelediğinden dolayıdır. ${ }^{62}$ Aynı şekilde Eş'arî, hissin, rüyetin. ve sem'in de mahsus, mer'î ve mesmu'un bilgisi olduğunu kabul eder. İbn Fûrek'in tesbitine göre Eş'arî, iki ayrı eserinde bunun aksine olarak Allah ın gören ve işiten diye vasıflanmasının merî ve mesm ’' olanları bilen anlamına gelmediğini de söylemektedir. İbn Fûrek, Eş'ar̂̂’nin usulü açısından doğrunun bu olduğunu söyler. Nitekim onun, idrakin idrak edilenin (müdrek) bilgisi olduğunu söyleyen Mutezilî düşünceyi kabul etmeyip onu bilgiden ayrı bir kavram olarak görmesi de bunu d’ğrular. Ona göre şek, cehl, sehv ve mevt gibi kavramlar, bilgiyle bir arada bulunmaları ve bir mevsufun aynı anda ikisiyle de vasıflanması imkânsız olan zıtlar cinsidir. ${ }^{63}$

Cüveynî ona nispet ettiğimiz bu tanımla ilgili olarak ilim, marifet fıkıh, dirayet, akıl, yakin ve fıtnat gibi değişik isim ve sözcüklerin kullanılmasının tanımın dogruluğuna zaras vermeyeceğini de söylüyor. Çünkü o bunların arasında anlam bakımınd:ın bir fark görmüyor. Ancak bunların Allah'a nispetinde bir farklılık olduğunu, bunun da Kitap ve sünnetteki kullanımlardan kaynaklandığını -Kitap ve sünnette Allah için sadece ilim sözcügü kullanılmakta, icma da buna muvafakat etmektedir- düşünüyor. ${ }^{64}$ Fakat aynı açıklamanın devamınđla Cüveynî, bunun tam tersi şeyler de söyleyerek sanki kendi içinde çelişkiye düşmektedir. Çünkü o, ilim dışındaki diğer isimlerin bilginin özel bires: türü olduğunu ve bunlardan oluşan bütünün ilim olduğundan bahsediyor. Bu durumda onun tanımda diğer lafızların kullanılabileceğine dair sözü p:ioblemli duruma düşer. Çünkü bilgiyi bunlardan biriyle tanımladığımızda bütünü cüz'üyle tanımlamıs oluruz ki, tanımın kapsamı sorunlu olur.

6) Cüveyni, Kâfiye, s. 25.

62 Kadı Abdülcebbar da ilimle marifeti, iliml: dirayeti aynı şeyler olarak görüyor ve bunlanın arasında bir farklılık ortaya koymanın gereksiz olduğunu söylüyor. Ilmin tebyîn, tahakkuk ve istibsar olarak isimlendirilmesini de doğru buluyor. Bunların şüpheden (şek) sonraki idrakler olduğunu sïylüyor. Bu sebeple Allah bunlardan yapılan bir nitelemeyle nitelenemez. Söz vb. bir şeyin manasını bilme söz konusu olduğunda bilgi, fehm, fıkh ve fitnat diye isimlendirilir. His: ise duyuların ilk bilgisi ya da hir organ vasitasıyla bilmedir. Bu sebeple Allah bununla vâsıflanamaz. Ilim akıl olarak da mecazen isimlendirilir. Çünkü akıl bütün bilgileri kapsamaz. Ilmin ihata ve idrak olarak isimlendirilmesi de böyledir. Yani tevessï/mecaz yoluylaciır. Bk. Kadî, Muğnî, XII, 16-7.

64 Cüveynî, a.g.e., s. 26. 
Başta Cüveynî, Gazzalî, ve Îcî gibi Eş'arî kökenli kelamcılardan gelmek üzere bu tanımlara yapılan bir takım eleştiriler de bulunmaktadır. Bunlar, tanım tekniği açısından yapılan eleştirilerdir. Cüveynî'nin eleştirisi, tanımda icmal yani maksadı tam ifade edemeyecek kadar kısalık oldugudur." Gazzalî ise, "âlim/bilen ve malum/bilinen lafızları "ilim/bilgi" lafzından türer, dolayısıyla kendisi bilinmeye muhtaç olan bir lafzı, türeyenleri ile tanımlamak onu bilinmez yapar" demektedir. ${ }^{60} \hat{\text { Îcî, tanımda }}$ devr/totoloji olduğunu, yani kendisiyle tanımlananla tanımlandığını ifade eder. ${ }^{67}$ Aslında bunların üçü de aynı şeyi, yani tanımda totoloji olduğunu anlatmaktadır. Củveynî'nin tanımda icmal olduğuna dair eleştirisi de bununla aynı anlamdadır. Zira icmal, totolojiden kaynaklanır.

$\mathrm{Bu}$ eleştiride bilgi, kişiye bilen vasfını kazandıran sıfat, bilen de, kendisinde bilgi vasfı olan diye tanımlandığında kısır döngü oluşacağı iddia edilmektedir. Bu eleştiri şu örnekle de desteklenir: Örneğin "Zeyd geldi" sözü söylendiğinde muhataplar "Zeyd kimdir?" diye sorarlar. Buna "Amr' in oğlu Zeyd" cevabı verilse, bu defa da "Amr kimdir?" denilse "Zeyd'in babasıdır" cevabı verilse bu durumda tanınmayan Zeyd, yine tanınmayan Amr'ın oğlu olmakla; tanınmayan Amr da yine tanınmayan Zeyd'in babası olmakla tanımlandığ tanımlananla tanımlanmış olacağından kısır döngüye düşülmüş olacaktır. ${ }^{68}$ Nesefî, Eş'arî'nin tanımına böyle bir örnekle yapılan eleştiriyi yersiz bulur. Çünkü bilginin bilenle tanımlanması demek, bilenin muhataplar tarafından mutlak-müphem bir bilgiyle de olsa bilinmesi demektir. Bilen, muhataplar tarafından bu şekilde de olsa bilindiğine göre, bilginin tanımı onlar için meçhul kalmayacaktır. Ama örnekte gösterilen Zeyd ve Amr isimli şahıslar muhatap tarafından hiç bilinmemektedir. Dolayısıyla onları birbiriyle tanımlamak muhatap için tam bir bilinmezlik meydana getirecektir. ${ }^{69}$

Bu örnekle tanıma yapılan itiraz, iki noktadan daha eleştirilebilir. Dikkat edilirse örnekte Zeyd'in tanınmadığı anlaşılmakta, fakat Amr'ın muhataplar tarafından tanınma ihtimali atlanarak onun da tanınmadığ varsayılmaktadır. Halbuki Amr'ın tanındığı varsayıldığında, onun kim olduğu sorusu sorulmayacak ve Zeyd muhatapların zihninde belirgin hâle gelecekti. Ayrıca örnekte gösterilen bilgi ile tanımda ortaya konulan bilgi arasında kanaatimizce fark vardır. Örnekteki bilgi tanımayla ilgili bilgidir; bu bir anlamda günlük bilgidir. Tanımda belirlenmeye çalışan bilgi ise felsefî anlamda bilgidir. Bu açıdan bakıldığında örnekle, örnek verilen konu uyuşmamaktadır. Dolayısıyla bu örnekle ortaya konulan izah tarzı isabetsiz görünmektedir.

\footnotetext{
Cüvcynî, Irşad, s. 34.

Gazzâlî, Mustasfâ, s.24.

Îcî, Mevakıf, s.10.

Nesefi, Tabsira, s. 16.

Nesefi, a.g.e., s. 16.
} 
Eş'an̂́'nin bu tanımınırı Nesefî tarafından da bir kısır döngü olduğu söylenerek eleştirildiği, bazı araştırmacılar tarafından söylenmektedir ${ }^{70}$; ama bu iddia tamamen hatalıdır ve Nesefî'nin metninin yanlış anlaşıldığının bir göstergesidir. Nesefî bu söylenenin tam aksine bunu kısır döngü olarak niteleyip de eleştirenlere kar:̣ı Eş'an̂̀'nin tanımını savunmaktadır. Nesefî'nin savunusu şöyledir:

"Herhangi bir şeyi bilmek bazen, onu başkalarından -ona uygun ve yakın olanlardan- ayıran gercek bir bilgiyle bilenin vukufiyetinde olmaksızın mutlak müphem bir bilgiyle olur. Bazen de onu başkalarından -ona uygun ve yakın olanlardan- ayıran gerçek bir bilgiyle bilenin vukufiyetinde olduğu gibi hakikî bir bilgiyle olur. Genelde halkın, Zeyd'in insan olduğunu bilmeleri böyledir. Bu, yakinî yolla sabit olan, bileni şüpheye, kalbini sıkıntıya düşürmeyen, şüphelerinden dolayı itiraz ettirmeyen, zihninde tereddütler doğurmayan bir bilgidir. Bununla beraber bu bilgi, müphem mutlak bir bilgidir. Avamdan olan insan, hayvanî kuvvetlerde ona münasip olanlardan ve ortaklıkta -özellikle akıl ve konuşmada- ona yaklaşanlardan insanı ayıran özelliklere ફ́erçekliğiyle vâkıf olamaz. Örneğin o, hâzık kelamcıların veya filozofların insanı, diğerlerinden ayıran hakikatiyle bildikleri gibi hakikî bir bilgiyle bilemez. Bundan, avamın Zeyd'in insan olduğuna dair olan bilgisirin gerçek bir bilgi olmadığını kastetmiyorum; aksine bu bilgi cehl, zan ve şek gibi bilginin bütün zıtlarını yok eden gerçek bir bilgidir. Ben sadece avamın bu bilgiyle insanın, insan olmayanlardan ayıran gerçekliğine vâkıf olamayacağını kastediyorum. Kelamcılar Zeyd'in insan olduğunu bilirler. Bi.nunla beraber onu insan olmayanlardan ayıran hakikatini da bilirler. Bu mukaddime sabit olunca biz şöyle deriz: Tanımlama, mutlak müpinem bilginin ispatı için konmamıştır -mutlak müphem bilgi tanımı bilməyenin bilgisidir- aksine o, onu başkalarından ayıran hakikatin bilgisini ispat için konulmuştur. Bundan dolayı bu özelliklerle tanımlananın biitün cüzlerinin toplanması ve başkalarının da bu özelliklerde ona ortak olmaktan uzaklaştırılması hasıl olur. Durum böyle olunca bilgi de, herkese göre ipham ve itlak yoluyla bilinmektedir, bilen de aynı şekilde ipham ve itlak joluyla bilinmektedir."71

Naklettiğimiz metindın de anlaşılacağ gibi Nesefî bilgiyi mutlakmüphem ve gerçek olmak üzere iki kısma ayırmakta ve hem bilgi, hem de bilen hakkında herkesin mutlak-müphem bir bilgisi olduğunu dolayısıyla bunların birbiriyle tanımlanmasının sonunda bilgisizlik (cehalet) çıkmayacağını söylemektecir. Bunun ötesinde Nesefî'nin kendisi de bilgiyi, "kendisinde olant bilen yafan sifat" olarak tanımlamakta ve "Biz diyoruz ki, bilginin hakikati, "kendisinde olant bilen yapmasıdır" demektedir." Nesefî'nin yaptığı bu savunmada öne sürülen formdan bilgisizlik (cehalet) çıkmaz ama yine mutlak-nüphem bilgi çıkar. Halbuki tanımlamanın amacı

Hanifi Özcan, Matüridî'de Bilgi Problemi, Istanbul 1993, s.34, 36.

Nesefi, Tabsira.s. 17-18.

2 Nesefí, Tabsira, s. 18. 
bir şeyin hakikatini açıkça ortaya koymaktır. Yani Nesefî'nin tabiriyle gerçek bilgiye kavuşmaktır.

Bilgiyi bir tür sıfat olarak tanımlayan bir başka kelamcı İmam Ebû Mansur el-Matüridî'dir. Ona nispet edilen bir tanımda bilgi, "kendisinde olduğu kimseye duyulur ve bilinir şeylerin açık olmasını/açık hâle gelmesini (yetecellâ/yencelî) săglayan bir sıfat" diye tanımlanır. ${ }^{73}$ Biz bunu, bilinenlerin kendisiyle bilindiği sıfat şeklinde ifade edebiliriz. Dolayısıyla tanım, lafzî farklılıkları bir tarafa bırakırsak Eş'arî'nin ilk sırada verdiğimiz tanımıyla aynıdır. Ona yapılan itirazlar bunun için de geçerli olur. Bu tanım Taftazânî'nin de benimsediği bir tanımdır. Tanımda kullanılan mezkûr kavramı hem mevcudu, hem madumu, hem duyuların idrakini, hem de aklın yakînî ve gayr-1 yakînî verilerini kapsar. ${ }^{74}$

Âmidî ise yapılan tanımları eleştirmekte ve bilgiyi, kendisiyle vasıflanan nefsin külli manalar arasını, zıddının ihtimali söz konusu olmayacak şekilde ayırma yeteneğini elde ettiği bir sifat olarak tanımlamaktadır. Âmidî tanımda kullandığı sıfat kavramını cins olarak görmekte ve onun özsel niteliğinin de küllî manalar arasını ayırma yeteneğini kazandırma olarak belirlemektedir. Bu son ibare ile o, duyuların cüzî idraklerini tanımın dışında tutmakta ve duyularla cüzî algıların belirlendiğini söylemektedir. ${ }^{75}$ Ancak Âmidî, kelamcılarla felsefecilerin kavramlarını açıklamaya tahsis ettiği el-Mübin kitabında bilgiyi burada verdiğimizden biraz daha farklı bir ifade ile tanımlamaktadır. $O$, bu eserinde bilgiyi, "olduğu durumun dişında bir duruma ihtimal vermeyecek sekilde bir mânânın nefiste meydana gelmesinden ibarettir" diye tanımlar. ${ }^{76}$

Bu tanım Îcî tarafından da küllî manalar sözü yalnızca manalar şeklinde yapılan küçük bir düzeltmeyle benimsenmiştir. Îcî'nin tercih ettiği tanım şöyledir: Bilgi, kendisinde bulunduğu kimse için karşıtına ihtimal vermeyecek şekilde manaların arasını ayırt etmeyi (temyiz) gerektiren sıfattır. Onun incelemesine göre bazıları "mana" sözcüğünü küllî, bazıları da aklî lafızlarıyla kayıtlamıştır. Birinci kayıt cüzîlerin bilgisini, ikinci kayıt ise duyuların bilgisini dışarıda bırakır. Dolayısıyla tanımdaki "mana" sözcüğü kayıtsız olarak bulunmalıdır. ${ }^{77}$

Eş'arî kökenli Ebû Bekr İbn el-Fûrek'in bilgiyi kişinin yaptığ sağlam yapmasını sağlayan sıfat olarak tanımladığı rivayet edilir. ${ }^{78}$ Bilgiyi böyle tanımlamak onu işlevsel olarak tasvir etmek ya da Gazzalî'nin deyimiyle "lazımıyla tanımlamak ve onu resmetmek" demektir. Ama bu

73 Nesefi, a.g.e., s. 19.

74 Taftazânî, Şerhu'l-akâid, İstanbul 1976, s.25.

75 Âmidî, Ihkâm, s.15.

76 Scyfüddin el-Âmidî, el-Mübîn fí elfâzı'l-hukemâ ve'l-mütekellimîn, thk. Hasan M. Safî̀, Kahire 1983, s. 119.

7 Îcî, Mevakif, s.11.

78 Nesefî, Tabsıra, s. 14; Îcî, Mevakıf, s.10. Aynı tanım Cüveynî (Irşad, s. 33-34) tarafından isim belirtilmeden verilmektedir.

79 Gazzâlî, Mustasfâ, s. 25. 
her türden bilgi için geçerli olan bir tanımlama değildir. Çünkü bizim bildiğimiz bir takım şeyler pratikte hiç de işimize yarayan şeyler değildir. Bu olsa olsa kudretin tanımıdır, tilginin değil. ${ }^{80}$

Matüridîlerden bir başka kelamcı bilgiyi, kendisinin varlı̆̆ıyla insanda, cehalet, şüphe, zan ve yanilinanin yok olduğu sifat diye tanımlamaktadır. ${ }^{81}$ $\mathrm{Bu}$ da bir şeyi zitlarıyla tanımlamak olduğundan pek makbul bir tanım olarak görülmemiştir.

Yukarıda verdiğimiz tanımların hepsi de lafzî farklılıkları, lafızların delalet ettiği anlamları dişta bırakırsak sonuçta birbirinin aynı olan tanımlardır ve onun bir sıfat olduğunu vurgularlar. ${ }^{82}$ Bilginin bir sıfat olarak tanımlanması ne anlama gelmektedir? Sifattan kasdedilen nedir? Bu gruptaki tanımlar dikkatle incelenirse bilginin insanda bir yeti olduğunun söylenmek istendiği kolayca anlaşılır. Yani bu tanımları yapanlar demek istemektedirler $\mathrm{ki}$, insanda bilgi diye bir: yeti var ve insan onunla bilme eylemini gerçekleştirir. Yani bilgi insanın bilme eylemini gerçekleştirdiği bir yetidir. Dolayısıyla bu tanımlarda bilgi değil, işleviyle birlikte bilgi yetisi betimlenmektedir. Halbuki tanımlanmaya çalışılan şey bilme yetisi değil, bu yetiyle yapılan bilme eylemi sonucunda oluşan zihnî durumdur. Bu da hem yetiden, hem de eylemden ayr $r$ bir şeydir.

Bilgiyi sıfat olarak tanımlamak karşımıza bir problemi daha çıkarmaktadır. Bu problem de tanımlanan bilginin kimin bilgisi olduğudur. Eş'an̂, Matüridî ve benzerlèrinin bilgiyi sıfat olarak tanımlamada güttükleri amaç; Allah'ın bilgisini de: tanım kapsamına dâhil etmektir. Nitekim Îcî bunu daha önce temas ettiğimiz üzere Bâkıllanî'nin tanımına yaptığı eleştiride açıkça söylemiştir. ${ }^{33}$

Yalnız, bilginin hem Allah'a hem de insana ait bir sıfat olduğunu söylemek, bu iki bilgi arıısında bir benzerlik olduğu düşüncesini zihne getirmektedir. Bunu daha baş̧tan gidermek için onlar, bilgiyi kadîm ve hâdis olarak ikiye ayırırlar. Kacî̀m olan, Allah'ın bilgisidir. Allah'ın sıfatları kadim olduğundan, bilgi sıfatı da kadîmdir. Beşerî bilgi ise, hâdis olup, Allah'ın yaratmasıyla vardır ve devamhlığı da O'nun var etmesine bağlıdır derler. ${ }^{84}$ Dolayısıyla onların bu ayrımı, tanıma yapılabilecek olan, sıfatların araz olup, Allah'ta bulunamayacağ ${ }_{1}$ şeklindeki bir itirazı ${ }^{85}$ daha baştan

Îcî. a.g.e., s. 10

81 Nesefí, a.g.e., s. 19.

\$2 Kadı Abdulcebbar'ın fikir l:avramını tanımlaması da bilgiyi bilinenlerin kendisiyle bilindiği sıfat diye tanımlamaya benzemektedir. O, fikrin kişinin mütefekkir olmasını gerektiren anlam olduğunu ve her insanın bu niteliği kendinde bularak mütefekkir olmakla olmamayı ayırt edcbileceğini söylemektedir. Kadı, Şerh, s.45.

83 Îcî, a.g.e., s.10.

84 İbn Fûrek, Mücerred, s.11.

85 Nitekim Ibn Hazm, bilginin bir sıfat olarak tanımlanmasını, sıfatların araz olmasından ve arazlann Allah'a nisbet edileıneyeceğinden hareketle eleştirir. Bu noktada o, âlim vasfının değil de alîm vasfının Allah'ı sıfat olarak Kur'ân'da kullanılmasını anlamlı bulur. Çünkü 
giderme amacını taşımaktadır. Fakat bunlar, bilgiyi tanımlamada sıfat kavramını bir amaca bağlı olarak kullansalar da temelde bir yanlışlık söz konusudur. Zira tanımlamaya konu olan beşerî bilgidir. Nitekim tanımın peşinden bilginin kaynakları konu edilir. $O$ hâlde tanımın Allah'ın bilgisini kapsamasını amaçlamak pek de anlamlı değildir.

İki bilgi arasındaki benzerlik probleminin Matürîdî tarafından bir başka şekilde de giderilmeye çalışıldı̆̆ Matürîdî̀'ye nisbet edilen tanımdaki yetecellâ fiiliyle beşerî bilgiden çok İlâhî bilgiye işaret edildiğini tespit etmektedir. Onun, Tevilat'tan hareketle yaptığı bu çıkarıma göre Maturîdî, bu kelimeyle mutlak ve vasıtasız, sebepsiz bilgiyi kastetmekte, beşen̂́ bilgi için de fıkıh, marifet gibi kavramları kullanmaktadır. ${ }^{86}$ Bunun doğru olduğunu kabul etsek bile karşımıza şöyle bir problem çıkacaktır: Yetecellâ kelimesi, bilinen nesne ile ilgili bir kavram olup, onun bilene kendisini açık bir şekilde arz etmesi anlamına gelir. Bu da onun önceden bilinmiyor olması demektir. Bu ise Allah'ın bilgisi açısından söz konusu edilemez. Bu en azından Sünnî teorisyenlerin Allah'ın bilgisi hakkındaki düşünceleriyle açık biçimde çelişir. Kullanılan kelimenin yencelî olduğunu -ki bu, kelimenin bir başka okunuşudur- hesaba katsak da durum değişmez. Çünkü o da önceden bilinmeyen bir şeyin açık hâle gelerek bilinmesi anlamına gelmektedir. Dolayısıyla bu fiille Allah'ın bilgisinin kastedildiğini düşünmek pek mümkün görünmüyor.

Tanım tekniği açısından bakacak olursak yukarıda tanımlarını verdiğimiz kelamcılar, sıfat kavramını bir cins ve bilgiyi de bu kavramın bir türü kabul etmekte; bu türün zatî vasfını da kendisinde olduğu kişiyi bilen yapması ya da konusu olan şeyleri kendisinde olduğu kişi için açık hâle getirmesi, bilinir yapması şeklinde tespit etmektedirler. Çünkü kendisinde olduğu kişiyi bilen yapması ya da konusu olan şeyleri kendisinde olduğu kişi için açık hâle getirmesi, o kimsedeki renk, tat, koku vb. diğer sıfat türlerinden dolayı olmayıp, bilgi sıfatından dolayıdır. Yani bilgi bir nitelik ilintisidir ve kendisinde olduğu kimseye bilen vasfını verir. Tıpkı siyahlığın kendisinde olduğu şeye siyah niteliğini vermesi gibi. ${ }^{87} \mathrm{Bu}$ açıdan bakıldığında pek bir problem gözükmüyor olsa da aslında tanım bu açıdan da problemlidir. Zira, sıfatları arazların içinde bir tür olarak düşündüğümüzde, örneğin renk, tat ve koku dediğimizde içinde fertleri barındıran türlerden bahsetmiş oluyoruz. Ama bilgiden bahsettiğimizde bir türden bahsetmiş olmuyoruz. Çünkü bilgiyi tür kabul edersek ferdi yoktur, fert kabul edersek türü yoktur. Dolayısıyla onu sıfat olarak tanımlamamız mümkün değildir. Bilginin fertleri olan bir tür olduğunu ortaya koyarsak, tanımın doğru olduğunu söyleyebiliriz. Aksi takdirde tanım doğru olmaz. Bilginin

alîm sıfat-ı müşebbehe kalıbı olup ism-i fail kalıbına nazaran sürekliliği ifade eder. (Ibn Hazm, Ihkâm, s. 44).

86

Özcan, a.g.e., s. 40-41.

*7 Nesefí, Tabsira, s. 18. 
fertlerinden maksat fertlerin bilgisi değil, bir cins olan bilginin içine girebilecek bilgi türleridir. Mutezili'lerin yaptığı gibi inanç cins kabul edilip, bilgi, zan, tereddüt, şüphe ve cehalet de onun türleri kabul edilirse belki problem çözüme kavuşur.

Bilgiyi bir sıfat olarak tanımlayan ibareleri bir araya getirirsek, onun, bilinenlerin kendisiyle bilindiği sıfat şeklinde tanımlandığını söyleyebiliriz. Bundan çıkaracağımız küllî önerme, "her bilgi, bilinenlerin kendisiyle bilindiği sıfattır" ş̧eklinde olur. Bunu döndürdügüüüzde ise, "bilinenlerin kendisiyle bilindiği her sifat, bilgidir" dememiz gerekir. Tard ve aks yönünden bu tanımda bir kusur gözükmemektedir. Kendisinde olduğu kimseyi bilen yapan sıfat diye tanımlandığında da durum farklı değildir.

\section{Bilginin Bir Tür Eylem Olarak Tanımlanması}

Bilgiyi bir tür inanç ve bir tür sıfat olarak tanımlayan kelamcıların yanı sıra, bir tür eylem olarak tanımlayanlar da vardır. Sözgelimi Nazzam'ın (0̈.236/862) bilgiyi, "kalbin hareketlerinden bir hareket" $\$ 8$ ya da "bulaca ğı şeyi bulması için kalbin hareketi" olarak tanımladığı rivayet edilir." Buradaki kalp; insan aklını karşılayan bir kavram olup, tanımda bilginin, zihnin bir eylemi olduğu anlatılmak istenmiştir. Yani zihnin bir şeyi kavramak üzerine yapmış olduğu eylem bilgi olmaktadır. Bir başka tanıma göre bilgi, "nazar edilen şevi kalbin görnesi" dir. ${ }^{90}$ Burada bilgi, kalbî görü olmaktadır ki bu tanım, sezgi, ilham gibi subjektif bilgi kaynaklarını da içerebilecek şekilde yapılmıştır. Hem Nazzan'ın tanımı, hem de söyleyeni belli olmayan bu tanım, teknik anlamda tanım kavramının henüz İslâm düşüncesine yerleşmediği erken dönem ürünüdïr.

Yukarıda saydığımız tanımlarda kullanılan hareket ve rü'yet kavramlarının bilgiyi tanımladıklarını düşünmüyoruz. Bunlar herhangi bir zamanla ilişkili olmaksızın bir eyleme delalet eden masdarlardır. Böyle bir tanımlama bilgiyi değil, anc:ak bilme eylemini anlatır. Bilgiyi eylem olarak tanımlamak, onun kalıcı olmadığını söylemek anlamına gelir. Çünkü eylemler belirli zaman aralıklarında meydana gelen sonra biten oluşlardır. Eylemlerin sonuçları ise $\epsilon$ n azından bir süre kalıcıdır. Diyelim ki ben masanın renginin siyah oldığunu biliyorum ve bir süre sonra masanın rengi değiştirilmiş ve mavi olmuş. Ben ondaki renk değişikliğini görmemiş ve onunla ilgili bir haber duyınamışsam, bu durumda ben hâlâ masanın siyah olduğunu bilirim. Sonra onun mavi oldığuna dair bir bilgi edindiğimde bile, unutuncaya kadar onun eskiden siyah olduğuna dair bilgi de aklımda kalır. Dolayısıyla bilgi bir eylem olarak tanımlanamaz.

Nosefi, a.g.e., s. 12. 


\section{Değerlendirme ve Sonuç}

Sondan başlayarak gidecek olursak yapılan tanımlar hakkındaki kanaatlerimizi şöylece belirtebiliriz: Bilginin bir eylem olarak tanımlanamayacağını düşünüyoruz. Çünkü o, bilme eylemiyle elde edilen bir sonuçtur. Bizim eylem kategorisinde değerlendirdiğimiz masdar kalıpları bir soyut varlığa delalet etmekten daha çok, herhangi bir zamana işaret etmeksizin bir eyleme delaletleri söz konusu olduğundan, bilginin onlarla tanımı mümkün görünmemektedir.

Kanaatimizce bilgiyi yeti olarak tanımlamak da pek isabetli değildir. Çünkü tanımlanan şey bilme yetisi değil, bilgidir. Tersi olursa, yani tanımıyla ilgilendiğimiz kavram bilgi değil de bilme yetisi olursa, onu sıfat kavramıla tanımlayabiliriz. Ama biz bilginin tanımıyla ilgileniyoruz. Bunun da ötesinde sıfatlar mantık bakımından tanımlanamazlar. Çünkü sıfatlar duyuların doğrudan tecrübeleriyle bilinirler. Ayrıca bu, dil açısından da mümkün değildir. Çünkü bilgiyi bir sıfat olarak tanımladığımızda "bilgi adam/racülün ilmun" gibi bir niteleme yapmamız imkânsızdır. Halbuki dilde bilmek fiilinden türetilen "bilen" vasfı nitelik olur ve "bilen adam/racülün alimun" denir. Bir de bilgiyle ilgili olarak yapılan tanımların sadece beşerî bilgiyi tanımlaması gerektiği kanaatini taşıyoruz. Zira inceleme konusu olan beşerî bilgidir. Konunun devamı olan bilgi vasıtalanı ve bilginin imkânı gibi hususlar da yine beşen̂ bilgiyle ilgilidir. Bu yüzden ilâhî bilgiyi ifade etsin diye tanımda sıfat kavramının kullanılmasını doğru bulmuyoruz.

Tanımda kullanılan kavramlardan bilgiyi tanımlayan en isabetli kavram kanaatimizce itikat kavramıdır. Bu kavram dil açısından da tanımlamaya imkân vermektedir. İtikat, Arapça'da bir masdar kalıbıdır. İnanmak eylemine de, soyut bir kavram olan inanca da delalet etmesi söz konusudur. İnanca delalet etmesi itibariyle o bir cins isimdir. Cins isimler de içlerinde türler barındırırlar. Dolayısıyla itikat kavramı bilgiyi bir tür olarak içinde barındıran ve içinde barındırdığı türler için ortak zihinsel zemini ifade eden bir kavramdır. Mutezili'lerin "bir şeye olduğu gibi inanmak" sözleri, bilginin gerçeğe uygun inanç olduğunu, "duyuların ve aklın zarurî bilgilerine veya mantıksal çıkarımlara dayalı olması" ilavesi de, onun kendiliğinden apaçık ya da istidlal yoluyla elde edilen, yani doğrulanmış bir inanç olduğunu, "kesin bir kanaat meydana getirmesi" ifadeleri de bilgide şüphe ve tereddüdün aksine olarak bulunması gereken kesinliği belirtir. Yapılan bu tanımlama eksik de olsa teknik anlamda bir tanım/had kabul edilebilir. Çünkü doğruluk onun ayırımı kabul edildiğinde kapsam problemi ortaya çıkmaktadır. Teknik açıdan pek makbul karşılanmasa da Cübbâî'nin ilavesi kanaatimizce kapsamdaki problemi gidermektedir. Kadi Abdülcebbar'ın ilavesi de tanımlamaya önemli bir katkı yapmaktadır. İtikat yerine Sünnîlerce kullanılan idrak ve marifet kavramlarının isim oldukları ve tanıma elverişli bulundukları düşünülebilir. Ancak bu durumda birincisinde bilgi, algı ile ikincisinde de eş anlamlısı/müradifi veya parçası ile tanımlanmış olur. Bunlar da doğru sonuçlar vermezler. 
Bilginin bu şekildeki tanımı, onların felsefî altyapısına da işaret etmektedir. Bilginin inanç kategorisi içinde tanımlanması, Platon'a (M.Ö.427-347) dayanır. Platon bilgiyi, "kantta dayanan doğru inaņ̧ olarak" tanımlamıştır." Buna göre bir şeyi tilmek için, o şeyin doğru olması, doğru olduğuna dair süjede bir inancın oluşması ve bu inancın yeterli kanıtlarla temellendirilmesi gerekir. Bir şeyin tek başına doğru olması ya da bir şeyin doğru olup olmadığını bilmeden ona ilişkin bir inancımızın olması onu bilmemizi sağlamaz. ${ }^{92}$ ()rneğin bir hâkim, sanık avukatının duygusal hitabetiyle sanığın suçsuzluğına inanabilir; bu inancı doğru da olabilir; ama bu onun suçlu olmadığını bildiğini göstermez..$^{93}$ Yine başka gezegenlerde yaşam olduğuna inanabilirim ve bu inancım doğru olabilir, ancak bu başka gezegenlerde hayat olduğunu bildiğin anlamına gelmez. Platon'un anlayışında bilgi doğru olabilecek önermelerle (olumsal doğruluklar) ilgili değil, doğru olan önermelerle (zorunlu doğruluklar) ilgilidir. ${ }^{94}$

Bu tanımlama biçimi modern felsefede de kabul görmüş̧ür. Bugün de bilgi tanımlanırken bir inanç formu olarak tanınlanmakta -en azından akılcı filozoflar tarafından- ve üç unsuru olduğu kabul edilmektedir. Bunlar, inanç, doğruluk ve kanıttır. Kesinlik ise doğruluk ve kanıttan kaynaklanmaktadır. ${ }^{95}$ Kısacası bilgi, inançlarımızı sağlam olarak temellendirdiğimizde sahip olduğumuz doğrulardır. "Bsilmek, özel türde bir inanç formudur. İnsan bilmeden de inanabilir. Fakat her şeyi bilmek, inanılan şey doğru olmadıkça bilmek anlamına gelmez. Dahası, inanılan şeyin doğru olduğu durumlarda bile, bilen ya da inanan kişi eğcr inancın temellerinin farkında değilse, söz konusu eylem bilmek'in kapsamı içinde yer almayacaktır.,"97

Bilginin inanç kavramıla tanımlanması, garip karşılanabilir. Fakat kanaatimizce bu isabetli bir seçimdir. Çünkü burada tanımlanan bilgi, felsefî anlamda bilgidir. Bu da şeyin ya da önermelerin bilgisidir (knowledge that); yoksa nasılın bilgisi (knowledge how) değildir. Bu iki bilgi çeşiti arasında şöyle bir fark söz konusudur. Birincisi bir şeyi örneğin, ilerde duran bir cismin araba olduğunu ya cla bir önermeyi örneğin, âlemin hâdis olduğunu bilmem gibi bilgilerdir. Ikincisi inançla ilgisi olmayan bir bilgi çeşididir. Örneğin birinin her hangi bir sanatı icra etmeyi, bir işi yapmayı bilmesi böyledir. A'nın resim yapmaayı, B'nin dıvar örmeyi bilmesi gibi. Buradaki bilme aslında becerme anlamındadır. Ama bunu, "A duvar, B resim yapmayı biliyor" şeklinde bir önermeye dökersek bu, A'nın duvar, B'nin de resim yapmayı bildiğine dair bir inancımızı ifade eden önermeye ait bilgi olur. Önermeye ait bilgiler de inanç alanına aittir.

91 Platon, "Theaitetos", (çcv. Micit Gökberk), Diyalogiar 2, İstanbul 1995, Remzi Kitabevi, s. $258(202 \mathrm{c})$.

92 Scdat Yazıcı, Felsefeye Giriş, İstanbul 1999, s.24-28

93 Quinton, "Knowledge and Belief", The Encyclopedia of Philosophy, IV , 347

* Jhon Cottingham, Akılctllk, çev. Bülent Gözkan, İstanbul 1995, s. 26-27.

95 Quinton, "Knowledge and Belicf", The Encyclopedia of Philosophy, IV, $345 \mathrm{vd}$

6 W. V. Quine; J. S. Ullian, Bilg̨i Ağı. Çev. Hadi Adanalı, Ankara 2001 , s.20.

o) Hüsamettin Aslan, Epistemik Eemaat, İstanbul 1992, s.85. 
Kelamın uğraşı alanı da şeyin veya önermelerin bilgisidir ve kelamcılar bu çeşit bilgiyi tanımlamak isterler. Dolayısıyla bilginin inanç olarak tanımlanması isabetlidir. Bunun en temel dayanağı bilmek ile inanmak fiillerinin nesnelerinin aynı olmasıdır. Örneğin, odada bulunan bir masa için "bunun masa olduğunu biliyorum" dediğim gibi "bunun masa olduğuna inanıyorum" da derim. Bu aslında her iki fiilin de aynı şeye işaret etmesinden kaynaklanmaktadır. Benim o şeyin masa olduğunu bilmem, aynı zamanda onun masa olduğuna dair inancı da beraberinde taşıdığım anlamına gelir. Benim onun masa olduğunu bilip de masa olduğuna inanmamam söz konusu olamaz. Ama bunun tersi mümkündür. Örnegin gökyüzünde gezen yuvarlak bir cismin ufo olduğuna inanabilirim; ama bu inancım onun ufo olduğunu bildiğim anlamına gelmez. Ancak bu inancım doğrulandığında bilgi olur. Bu durumda ikisi arasında bir içlem kaplam ilişkisi gözükmektedir. Her inanç bir bilgiyi ifade etmezken, her bilgi bir inancı ifade etmektedir.

Dilin örtüşük olmasından kaynaklanan bazı ifade ve kullanımlar bilgiyle inanç arasında bir iliş̧kinin olmadı̆ğ ve hatta bir çelişkinin olduğu düşüncesini doğurabilir. Örneğin "T (Hristiyan bir şahıs) İslâm'ı biliyor; ama ona inanmıyor" deriz. Bu sözdeki bilme ile inanma arasında bir çelişki var gibi gözükmektedir. Buradaki bilme aslında ya tanıma (marifet-to recognize) ya da hakkında bilgi (knowledge of) anlamında kullanılmaktadır. Bu anlamlardaki bilgi de inanmayla ilgilidir. Bir kimsenin Islâm'ı bilip de bildiği şeyin İslâm olduğuna inanmaması söz konusu olamaz. Dolayısıyla İslâm olarak bildiği şeyin İslâm olduğuna da inanması gerekir. Bu ifadenin ilk kısmıyla ilişkili önermeler kurduğumuzda bu önermelerin de inançla ilgili olduğunu görürüz. Örneğin “ $T$ İslâm'ın temel hükmünün tevhit inancı olduğunu biliyor" önermesi aynı zamanda onun İslâm'ın temel hükmünün tevhit inancı olduğuna inanmasını da gerektirir. Çünkü onun Íslam'ın temel hükmünün tevhit inancı olduğunu bilip de onun temel hükmünün tevhit inancı olduğuna inanmaması mümkün değildir. T'nin İslâm'ı bilip de ona inanmamasını ifade eden ikinci kısımdaki inanma aslında iman etme anlamında kullanılmaktadır. Bu anlamdaki inanma ile bilme ayrışırlar. Buna bağlı olarak T'nin İslâm' ın temel hükmünün tevhit inancı olduguna inanması onun tevhit inancında olduğu anlamına gelmez.

Sonuç olarak bilginin kişinin kesin bir kanaat duyduğu, belli bir kaynağa dayanan doğru inanç olduğunu söyleyebiliriz. Bir inanç doğru ve belli bir kaynaktan elde edilmiş olmakla birlikte kişi o konuda mutmain değilse bu zihinsel duruma şek deniliyor. Kesin kanata sahip olduğu halde kişi o inancını belli bir kaynaktan elde etmemişse o da bilgi olmuyor, zan oluyor. Kişi kesin kanaate sahip, fakat inancı doğru değilse bu da cehalet oluyor. 